Cahiers $d u$ MONDE RUSSE

\section{Cahiers du monde russe}

Russie - Empire russe - Union soviétique et États indépendants

57/2-3 | 2016

Famille et mobilité sociale en Russie, XVIe-XVIIle siècles

\title{
The Tomilovs, Siberian Petty Noblemen
}

Career, social connections and lifestyle at the age of transition from tsardom to empire ${ }^{1}$

Les Tomilov, cadets de province de Sibérie : carrière, liens sociaux et mode de vie au moment de la transition à l'empire

Viktor E. Borisov

\section{OpenEdition} Journals

Electronic version

URL: http://journals.openedition.org/monderusse/8366

DOI: $10.4000 /$ monderusse. 8366

ISSN: $1777-5388$

\section{Publisher}

Éditions de l'EHESS

\section{Printed version}

Date of publication: 1 April 2016

Number of pages: $423-456$

ISBN: 978-2-7132-2541-3

ISSN: $1252-6576$

\section{Electronic reference}

Viktor E. Borisov, «The Tomilovs, Siberian Petty Noblemen », Cahiers du monde russe [Online],

57/2-3 | 2016, Online since 01 April 2019, Connection on 03 May 2019. URL : http://

journals.openedition.org/monderusse/8366; DOI : 10.4000/monderusse.8366

This text was automatically generated on 3 May 2019.

(c) École des hautes études en sciences sociales 


\title{
The Tomilovs, Siberian Petty Noblemen
}

\author{
Career, social connections and lifestyle at the age of transition from \\ tsardom to empire ${ }^{1}$ \\ Les Tomilov, cadets de province de Sibérie : carrière, liens sociaux et mode de vie \\ au moment de la transition à l'empire
}

Viktor E. Borisov

\section{EDITOR'S NOTE}

Translated from Russian by Deniza Mansurova

\section{AUTHOR'S NOTE}

${ }^{1}$ The study was implemented in the framework of the Basic Research Program at the National Research University Higher School of Economics (HSE) in 2015.

1 Although such approaches as microhistory, Alltagsgeschichte or community studies have already been implemented in a significant number of papers in Russian social history, researchers have apparently not lost hope of reaching new conclusions by using these methods.

In this respect, the discussion on the "soslovie (estate) paradigm" recently revived by Michael Confino is remarkable. It was launched with a rather radical thesis: "[...] soslovie as a tool of social analysis is inadequate and insufficient for imperial Russian society at any time."2 However, most commentators (Elise Wirtschafter, David Ransel, Alexander Kamenskii) have left aside the question of the heuristic significance of the estate paradigm, preferring instead to emphasize the uncertainties connected with the use of this, and other terms (klass or chin), to describe Russian society. ${ }^{3}$ Nearly all their 
suggestions for a "better solution" are illustrated with more or less detailed case studies. Elise Wirtschafter draws upon court cases demonstrating that "the legally defined categories of Russian Imperial society did not necessarily correspond to social and economic facts... They were defined, applied, and manipulated in varied and often contradictory ways both by the government and by individuals and collectivities in society." ${ }^{4}$ Referring to his monograph on the diary of merchant Ivan Tolchënov, David Ransel points out that it is possible to study the interactions of persons belonging to different estates based on personal records, while Alexander Kamenskii suggests an analysis of provincial books of protested promissory notes.

This paper explores the same issues (the usage of legally defined social categories and norms by ordinary people and the state; interactions of persons belonging to different social groups), drawing on the biographies of two Siberian servitors (pl. deti boiarskie) living at the time of transition from the Muscovite to the Imperial period. Our research seeks to affirm both the weakness and strength of the social boundaries created by the state; it also does not claim to prove that official categories (soslovie, rang, chin, ${ }^{5}$ etc.) are completely inadequate for describing social reality. In our opinion, some heterogeneity and blurred boundaries are inevitable features of every large social group. ${ }^{6}$ It is therefore natural that focus on personal histories should bring to light some important subdivisions and practices. However, our analysis purports to be complementary rather than alternative. ${ }^{7}$

\section{The Tomilovs in Verkhotur'e}

Deti boiarskie Fëdor and Ivan Tomilov, sons of Pankratii (Pankrat'evy deti Tomilovy) first caught our attention with several curious cases related to their conflict with Verkhotur'e Governor (voevoda) Ivan Tsykler. Wishing to broaden our knowledge of the context of the conflict, we gradually came to study the Tomilovs' activities throughout their lives. This allowed us to make several observations about the social development of Western Siberia in the second half of the seventeenth and first quarter of the eighteenth centuries that, on the one hand, show several important unofficial practices and on the other hand, confirm the ability of the state to affirm and change social hierarchy in spite of these practices.

5 In European Russia, provincial deti boiarskie were the lowest stratum of hereditary service (sluzhilye liudi po otechestvu). In Siberia however, their position was significantly different. As there was no gentry cavalry militia (dvorianskoe opolchenie) beyond the Urals, deti boiarskie were not granted estates (pomest'ia). This is why their principal functions were those which were considered complementary to regimental service in the historical centre of the country: running peasant volosti or slobody (settlements wooden fortresses with adjacent villages), serving as heads (golovy) of Cossack, musketeer (strel'tsy) or Tatar troops, heading military expeditions and embassies to representatives of nomadic nobility, handling large purchases, building wooden fortresses (ostrogi), collecting iasak (a tax in kind exacted from the indigenous peoples of Siberia), etc. The larger share of administrative duties in comparison to the centre of the country, remoteness from the sovereign's court (gosudarev dvor) and major military theatres had contradictory consequences. On the one hand, the status of service in Siberia was very low in the Russian service hierarchy. It is significant that exiled persons and non 
-hereditary servitors (sluzhilye po priboru) were actively initiated (verstat'sia) into deti boiarskie. ${ }^{8}$ In the eighteenth century, only few of them were able to prove their nobility.

On the other hand, the de facto role that the representatives of the group played in the life of the region gives good reason to describe Siberian deti boiarskie as a local military and administrative elite. While the higher status groups of the Muscovite state were represented only by newcoming governors, middle ranking executives had a key role in organising virtually all socially significant activities, thus gaining considerable income.

7 The father of Fëdor and Ivan Pankrat'evy deti Tomilovy, Tomila (Pankrat) Nefedov syn Serebrianik, together with his brother Bogdan, started his service as a musketeer in Verkhotur'e (1623-1624), then moved into cannoneers (pushkari) and several years later reached the rank of musketeer desiatnik (head of a ten-person squad). In 1654, he founded Krasnopol'skaia sloboda and finally obtained the rank of syn boiarskii. After the military muster (razbor) of 1659-1660, he became a desiatnik again, but in 1663 he succeeded in defending his rank as syn boiarskii in Moscow and died the same year. ${ }^{9}$ At that moment, his elder son Fëdor was around 17 years old, his younger son Ivan - around $10 .^{10}$ The 1666 census book does not report Fëdor's age, which means he married before the age of $20 .{ }^{11}$ In May of the same year, Fëdor Tomilov was entrusted with his first known mission: Governor Ivan Iakovlevich Koltovskii sent him to search for and identify the peasants of Irbitskaia sloboda in the settlements of Tobol'sk district (uezd). ${ }^{12}$ However, it was not until 1668 that Fëdor was initiated and assigned the rank of syn boiarskii and given 7 out of the 10 roubles of his father's entitlement (oklad) ${ }^{13}$ following a report (otpiska) from Tobol'sk Governor Pëtr Godunov. The initiation (verstanie) seems to have taken place at the beginning of the year, since in March, Fëdor Tomilov was already running the largest Verkhotur'e settlement - Nev'ianskaia sloboda. He ran it at least until October 1670, with an absence in February-April 1669 for a trip to Sol' Kamskaia where he collected some possessions previously entrusted to a townsman (posadskii chelovek), Pëtr Afanas'iev. ${ }^{14}$ In autumn 1670, he was a zamolotchik (he supervised the threshing of the grain collected by peasants from the field belonging to the tsar). ${ }^{15}$ In August 1671, Fëdor Tomilov was the prikazchik (local official ruling a settlement) of Chusovaia sloboda. ${ }^{16}$ This administrative unit had a rich history. In fact, Fëdor's father was appointed to run it twice (in 1654-1655 and 1662). In 1662, the settlement suffered a devastating Bashkir raid. However, it also had a customs post, ${ }^{17}$ which probably increased its potential for providing presents and bribes. On July 31, 1672, Fëdor Tomilov is referred to as vydelshchik (person responsible for the allocation of part of the grain to the treasury). ${ }^{18}$ In August 1672, we find him again as the prikazchik of Chusovaia sloboda. ${ }^{19}$ On January 31, 1673, Fëdor Tomilov was appointed to run Aramashevskaia sloboda, one of the biggest settlements of the district. ${ }^{20}$ In October 1674 , he was apparently replaced by another Verkhotur'e syn boiarskii - Mikhail Ivanovich Meshcheriakov. The latter's conflict with Fëdor Tomilov allows us to add some vivid details to the so far rather formal summary of Fëdor Tomilov's service.

In a petition (chelobitnaia) filed on October 27, 1674, Mikhail Meshcheriakov stated that he had been orally informed by the wife of Feofan Lazarev - a belomestnyi Cossack ${ }^{21}$ - and his son Koz'ma that Feofan was in danger. During a feast held by Vasilii Serebriannik, another belomestnyi Cossack, Fëdor and Ivan Tomilov locked Feofan, gave him a beating, and tried to stab him. Guards (karaul'shchiki), also belomestnye Cossacks, were sent to the premisses and took Feofan to the prikazchik's office (sudebnaia izba). However, Fëdor, his brother and his men ran to the prikazchik's office with clubs (oslop'e). The place was 
occupied only by the guards, a scribe and a janitor (komornik). At the sight of their mischief (ozornichestvo), Meshcheriakov ordered to ring the bell in order to prevent slaughter. At that moment, Ivan Zagurskii, Verkhotur'e syn boiarskii and zamolotchik, and belomestnye Cossacks ran to the prikazchik's office. Fëdor and his men fought them off, then broke in and grabbed Meshcheriakov by the throat, "saying: you are not worthy to sit in my place! And he hurled obscenities at Mikhail, called him a thief and a traitor, accused him of lese-majesty (velikoe gosudarevo delo), and threw window bolts (zaporki) at him. They also beat the scribe and belomestnye Cossacks sitting at the table." Zamolotchik Zagurskii calmed the troublemaker down. Fëdor Tomilov was eventually put under lock and key, but the following morning he left after beating off the guards. ${ }^{22}$ The Cossacks' report (doezd) and testimonies (skazki) by witnesses (peasants, itinerants [guliashchie liudi] and guards) were similar to Meshcheriakov's story and included some additional details. In particular, we learn from these documents that Vasilii Serebriannik, the organizer of the feast, was a cousin of the Tomilov brothers; the guards got into the house only at the second attempt, saying they just wanted to join the gathering; Feofan was saved from injury and eventual murder by women who shielded him; there were five Cossack guards. ${ }^{23}$ The "dossier" sent by Mikhail Meshcheriakov and received in Verkhotur'e on November 5, 1674, ${ }^{24}$ also included a petition by nine belomestnye Cossacks from Aramashevskaia sloboda against Fëdor Tomilov and his brother:

In the past, ours lords, in the year 182 and this, the year $183,{ }^{25}$ Fëdor and his brother and his men shamelessly came to our houses and hit us, and tore our beards off... and slapped our wives on the cheeks... Our daughters and wives get no break from Fëdor and his brother... because Fëdor and his men seize our daughters in the street and take them to his homestead against their will.

The petitioners claimed, "Life has become impossible" (zhit' stalo ne vmoch) and asked to have "Fëdor removed from Aramashevskaia sloboda" (Fedora iz Aramashevskoi slobody perevest' ${ }^{\prime}{ }^{26}$

The following points about the social organization of Siberia should be emphasized. Although in Siberia the lowest administrative level was more significant than in, for instance, Pomor'e, a prikazchik could hardly continue fulfiling his duties in case of a conflict with "powerful men." Fëdor and Ivan Tomilov, their serfs and three cousins, the Serebrianniks, can be considered such "powerful men." Judging from the evidence presented at the investigation, the prikazchik could count on the majority of the Cossacks (nine persons supported the petition against the Tomilovs), the scribe and peasants; another syn boiarskii, zamolotchik Ivan Zagurskii, also seems to be on Meshcheriakov's side. However, Mikhail Meshcheriakov's supporters could not be ignorant of the fact that he might be replaced at any moment, while the Tomilovs would always be present in the settlement to one extent or another.

11 In the end, the Tomilovs did not venture to seriously attack socially equal Meshcheriakov and Zagurskii, at least not in the presence of the people who had gathered there, alarmed by the bell. However, the Tomilovs easily disposed of the belomestnye Cossacks - the fact that Fëdor Tomilov left the guards unharmed suggests that the Cossacks did not dare to offer substantial resistance, even though in terms of genealogy and lifestyle, the distance between them was not significant. Vasilii Men'shoi Serebriannik, the feast organizer, was a cousin of the Tomilovs (a son of Tomila's brother Bogdan). Bogdan's other sons also lived in Aramashevskaia sloboda : pop (priest) Fëdor and a second Vasilii, referred to as priest's brother in the 1669 census. $^{27}$ Similarly, the Tomilovs' opponent, Mikhail Meshcheriakov, had kins among representatives of lower status groups. His 
father was a clerk (pod'iachii) in Tiumen', while his own brother Zakharii occupied the very modest post of scribe (d'iachok) in the prikazchik's office of Belosudskaia sloboda without any monetary allowance. Interestingly, the main victim, Feofan Lazarev, used to be a sexton (ponomar') before his recruitment into belomestnye Cossacks. Consequently, not only was he Vasilii's colleague, but Fëdor Serebriannikov's as well. In addition, he could possibly be an in-law to one of them. ${ }^{28}$ Hence, the above-mentioned conflict clearly demonstrates both the porosity of social boundaries in everyday life (blood relationships between people of different statuses, shared leisure activities) and the fact that people were very conscious of them (belomestnye Cossacks are powerless in front of deti boiarskie).

Mikhail Meshcheriakov may have initiated belomestnye Cossacks' common complaint against the Tomilov brothers. Yet both the materials of the case and data from subsequent investigations (see below) coupled with the content of several collective petitions filed in the $1690 \mathrm{~s}^{29}$ confirm that in general, the reviewed petition correctly describes the Tomilov brothers' behaviour towards their subordinates.

During the investigation in Verkhotur'e, Fëdor and Ivan claimed that it was they who were beaten, "God knows why" (nevedomo zachem), by belomestnye Cossacks at the prikazchik's instigation, and that Fëdor made accusations of lese-majesty in order to avoid severe injuries. However, they pointed out that Mikhail Meshcheriakov had not yet verified the inventory of state property. ${ }^{30}$ Since Ivan Tomilov had not accused anybody of lese-majesty, he was released on bail. The list of his guarantors is quite surprising: it is composed of two clerks, three musketeers, one townsman, but not a single syn boiarskii. ${ }^{31}$ Taking into account the fact that deti boiarskie are quite often found even among guarantors of peasants, ${ }^{32}$ their absence from the list of Ivan Tomilov's guarantors suggests that the latter had difficult relations with 'colleagues.' The documentation mentioned above is followed by an excerpt from the Law Code of 1649 (Ulozhenie) on the punishment of knouting for false claims of lese-majesty. ${ }^{33}$ Nevertheless, contrary to expectations, the dossier is not completed by the sentence and a record of its enforcement, but by a petition filed by Fëdor one month after the face-to-face confrontation (on December 25) begging for mercy on the occasion of Grand Princess Feodora Alexeevna's anniversary. ${ }^{34}$ Since this document is the last in the dossier, we may surmise that Fëdor Tomilov managed to escape punishment.

With this in mind, let us attempt to compare the first decade of Fëdor Tomilov's independent life with the experience of other Verkhotur'e deti boiarskie in the second half of the seventeenth century. The start of his career seems to be rather complicated. It took Fëdor five years to be initiated and assigned his father's entitlement, while the sons of other deti boiarskie, if they were fit for service, normally obtained their fathers' positions within shorter periods. For instance, Mikhail Afanas'evich Bibikov got his father's place in approximately two years (his father died in 1664-1665 and he was initiated in May 166735). Fëdor Fëdorovich Kamenskii was initiated the year of his father's death (though in the extraordinary circumstances of a Bashkir uprising). ${ }^{36}$ Similarly, Ivan Evdokimovich Albychev and Mikhail Ivanovich Tyrkov were assigned an entitlement soon after their fathers' death ( $1671^{37}$ and $1663^{38}$ respectively). It should be emphasized that Tomila Nefed'ev's entitlement was vacant from 1663 to 1668; moreover, several other entitlements became vacant in 1665 (those of Fëdor Golovkov, Grigorii Chertkov, Andrei Bernatskii). ${ }^{39}$ 

from their father Tomila Nefed'ev was not sufficient for them to automatically secure the status he had obtained. Monetary savings might have facilitated bureaucratic procedures, but Tomila Nefed'ev's visit to Moscow apparently led to a significant decrease in the Tomilovs' capital. This allows us to carefully surmise that the successful launch of Fëdor's career was made possible by a advantageous marriage entered into around 1666 . The decision of Verkhotur'e governor's office (voevodskaia izba) concerning the Tomilovs and the composition of Ivan Tomilov's list of guarantors in the 1674 investigation suggest that the Tomilovs' in-laws belonged to clerks rather than deti boiarskie.

When 23-year-old Fëdor was officially initiated and assigned his father's entitlement following a report from Tobol'sk governor, his service proved very successful. With only short interruptions he occupied the very profitable post of prikazchik in settlements that were far from the worst in terms of feeding (kormlenie) and opportunities for taking bribes (approximately 5 years out of 6.5 from March 1668 till October 1674). He managed to get out of a very complicated case despite the fact that he had dishonoured a person of equal status on duty and used such a dangerous instrument for a complainant as lesemajesty.

17 According to Fëdor Tomilov's petition for payment of remuneration for the "previous 7181 (1672-1673) year," filed in February 1675, after the scandal, he was included in the list of servitors to be sent to Tomsk. ${ }^{40}$ In January 1679 , he was sent to his native Aramashevskaia sloboda to investigate Savva Kuznets's complaint about being beaten by prikazchik Alexandr Ushakovskii and belomestnye Cossacks ${ }^{41}$.

During the 1679 muster, Fëdor, like other deti boiarskie who were not initiated pursuant to a tsar's order [ne po gosudarevoi gramote], was deprived of his entitlement. However, unlike Iakov Lepikhin and several others, Fëdor Tomilov was a second-generation syn boiarskii. Together with other victims of the muster, he successfully petitioned for a tsar's order. On June 27, 1681, the Siberian Chancellery (Sibirskii prikaz) sanctioned restitution of Tomila Nefed'ev's entitlement to Fëdor, as well as approved initiation into deti boiarskie of his brother Ivan. Subsequently, this order was confirmed on August 6, 1681, by Verkhotur'e governor's office (prikaznaia izba). ${ }^{42}$

Information about Fëdor's subsequent life is less ample. However, it can be said with certainty that he continued primarily to exercise prikazchik functions in different settlements, gravitating, as in the 1670s, around the same Aramashevskaia and Utkinskaia slobody. In an otvodnaia (document defining the limits of a land parcel and granting corresponding rights) dated July 1682 , he is referred to as the prikazchik of Nev'ianskaia sloboda. ${ }^{43}$ In October 1682, Fëdor is listed among the deti boiarskie who were absent at the oath to Ivan and Pëtr Alekseevich because "they were sent to settlements on tsar's missions" (poslany dlia gosudarevykh del $\mathrm{v}$ slobody). ${ }^{44}$ According to a record in the entitlement book (kniga okladnaia vydachi denezhnogo zhalovaniia) entered in 16831684, "he was not given the first half of the entitlement for cash remuneration because he was on duty running Aramashevskaia sloboda till March" (denezhnogo zhalovan'ia polovinnyi oklad dat' ne dovelos', potomu chto on byl do marta mesiatsa $v$ Aramasheve slobode na prikaze). ${ }^{45}$ In November 1688, we find Fëdor in Aramashevskaia sloboda again, ${ }^{46}$ while at the end of May-early June 1689, his successor Ivan Dirin reported to Verkhotur 'e that Fëdor Tomilov "had not checked the list [of grain and military stocks] with him and left for Chusovskaia sloboda" (ne rospisalsia i s"'ekhal v Chiusovskuiu slobodu). ${ }^{47}$ 
20 Fëdor Tomilov did not receive any remuneration in 1691-1692 either, because of his duties as prikazchik of Aramashevskaia and Utkinskaia slobody. ${ }^{48}$ The same was true for 1693-1694: "On March 1, there was no reason [to pay renumeration] because he was on duty running Chusovskaia sloboda" (marta 1 chisla ne dovelos', potomu chto byl na prikaze v Chiusovskoi slobode). ${ }^{49}$ By May of the same year, Fëdor Lisitsyn replaced Fëdor Tomilov. ${ }^{50}$

21 In 1682, the krestoprivodnaia kniga (oath book) of Aramashevskaia sloboda records Fëdor Tomilov's son Pimen as well as, for the first time, his nephew Kirilo Stepanov. ${ }^{51}$ It remains unknown whether the latter was a relative through parental or female lineage since there is no available data on Tomila (Pankrat) Serebriannik's brother Stepan. Be that as it may, he remained included in the list of "uninitiated (neverstannye) deti boiarskie" as Fëdor Tomilov's relative till old age. He is reported as "Kirilo Stepanov syn Tomilov," 51 years old, in the 1710 census. He resided in Beloiarskaia sloboda with his wife, 15-year-old son Vasilii and four daughters. ${ }^{52}$ The 1720 census finds Kirilo and his son (women are not recorded) in the same place. ${ }^{53}$

Ivan Tomilov's career was even more successful. According to the recollections of the elder and peasants of Irbitskaia sloboda gathered in $1698,{ }^{54}$ he became the prikazchik of Irbitskaia sloboda (a large settlement and the centre of the famous fair emerging at that time ${ }^{55}$ ) even before his official initiation in $1680 .{ }^{56}$ According to available data, this may have happened between February and November 1680 - before and after this period Vasilii Protopopov occupied the position. ${ }^{57}$ In 1682, Ivan Tomilov ran his native Aramashevskaia sloboda. ${ }^{58}$ The testimonies of Irbit peasants show that Ivan Tomilov ruled Irbitskaia sloboda for a short time in autumn 1683 before running Nev'ianskaia sloboda. However, he spent six months doing some less profitable assignments, since he received remuneration for this period. ${ }^{59}$ In October 1684, he (still?) served as prikazchik in Nev 'ianskaia sloboda.$^{60}$ In 1686-1687, Ivan Tomilov founded Beloiarskaia sloboda on the river Pyshma. ${ }^{61}$ What follows is a description by a peasant of neighbouring Novaia Kamyshevskaia sloboda, founded by the peasant Grigorii Sysoevykh practically simultaneously with Beloiarskaia (officially in November 1686 ) ${ }^{62}$ : "On the lands given by otvodnaia on the river Pyshma, Verkhotur'e syn boiarskii Ivan Tomilov constructed a settlement following a memo (pamiat') from Verkhotur'e. He neither petitioned the Tobol'sk administration nor invited them to inspect the place. He seized the best lands, and the dwellers of that settlement [established by Tomilov] oppressed the slobodchiki and peasants [living in Novaia Kamyshevskaia sloboda]." ${ }^{63}$ In 1687, Ivan was given a grain allowance consisting of 3 chetvert ${ }^{\prime 64}$ of rye and the same amount of oat, probably as a sign of encouragement (prior to that, he got his grain from the field) ${ }^{65}$ The same year (before May 5), ${ }^{66}$ he was appointed as prikazchik of his native Aramashevskaia sloboda, previously run by his elder brother Fëdor (see above). Subsequently, Metropolitan Pavel accused Ivan Tomilov of appropriation of the lime made by church workers (rabotnye liudi), ${ }^{67}$ and the prikazchik was sent to Tobol'sk to be investigated.

The following year, Ivan Tomilov served again as prikazchik and entered a new conflict with ecclesiastical authorities. In July 1688, Irbit priest Grigorii Nikiforov and deacon Samson Mikhailov filed a complaint against prikazchik Ivan Tomilov to Metropolitan Pavel of Tobol'sk, accusing him of "numerous offences against the Church, losses, beatings, devastation, and spiritual affairs." ${ }^{68}$ Pavel's report (otpiska) to Verkhotur'e Governor Grigorii Filimonovich Naryshkin prescribing to send the prikazchik to Tobol'sk under the threat of stopping church services in the settlement suggests that the 
complaint was probably related to Ivan Tomilov's position in the conflict between the peasants and the parish scribe (tserkovnyi d'iachok). ${ }^{69}$ In May of the same year, Tomilov sent a report on mutual accusations of "vorovstvo" (the term could mean almost any type of crime) made by Fëdor Zhilin, peasant, and Pavel Ivanov, parish scribe, to Verkhotur'e. The report suggested sending both plaintiffs to Verkhotur'e. Instead, "the priests and the deacon forcibly expelled Pashka Ivanov from the musketeers," apparently on the grounds that ecclesiastic authorities had exclusive jurisdiction over the parish clerk. On March 6, 1689, Ivan Tomilov was mentioned as the prikazchik of Chusovskaia sloboda ${ }^{70}$ and returned to Irbitskaia sloboda ${ }^{71}$ as soon as March 24 of the same year (where he apparently stayed till June ${ }^{72}$ ). From November 1690 to February 1691, Ivan Tomilov served once again as prikazchik in Irbitskaia sloboda. ${ }^{73}$ In $1691-1692$, according to the entitlement book (okladnaia kniga denezhnogo zhalovaniia), he ran Nev'ianskaia and Belosludskaia slobody. ${ }^{74}$ In May 1692, his style of running Belosludskaia sloboda gave rise to a series of peasant petitions; moreover, according to the prikazchik's complaints, the starosta refused to obey his orders..$^{75}$ However, this did not prove an obstacle to Tomilov serving as Turinsk governor between October 1692 and February 1693. He replaced Bogdan Chelishchev, who was dismissed as the result of an investigation..$^{76}$ In 1693 , Tomilov served again as prikazchik in Irbitskaia sloboda (for approximately six months: Mikhail Bibikov and his son are also referred to as prikazchiki for that year $\left.{ }^{77}\right)$. Ivan returned again as prikazchik in December 1693 and remained in this position until late January-early February 1695, with an interruption in May and June 1694, when he was sent to Tobol'sk with a grain supply. In the interim, he was replaced by Tikhon Golovkov. ${ }^{78}$ As far as we can see, at that time Ivan was one of the most influential Verkhotur'e deti boiarskie: he had founded a new settlement, performed the duties of Turinsk governor, served for a long time as prikazchik of Irbitskaia sloboda, where the fair had already taken shape and was gathering pace. At the same time, he remained influential in Beloiarskaia sloboda (the report requesting the appointment of a substitute for the period of his trip to Tobol'sk contains a message that some timber had been prepared in Beloiarskaia sloboda for fort construction). The governor's reply memo addresses him with the patronymic ending -evich, while most deti boiarskie were addressed by their full first name without patronymic..$^{79}$

It can be assumed that the part of the Tomilov brothers' biographies that we have just reviewed (1680-1695) coincided with several social processes that have not been thoroughly studied yet. At the end of the 1660s and in the early 1670s, the number of Verkhotur'e deti boiarskie dramatically increased. In 1660, 17 persons were registered in Verkhotur'e.$^{80}$ In 1666 , due to a natural decline in population and reassignment of several deti boiarskie to cavalrymen (reitary), their number fell to four, ${ }^{81}$ while in 1668 there were seven deti boiarskie. ${ }^{82}$ Yet, the 1669 census shows 16 local deti boiarskie (restored back from reitary or newly initiated) and an equal number of foreigners (inozemtsy) of the same status who opted to remain in the Russian service after the armistice of Andrusov. ${ }^{83}$ In 1671, the number of deti boiarskie increased to 44 and did not fall below 40 until at least $1692,{ }^{84}$ then decreased to 34 by $1698 .{ }^{85}$ Meanwhile, the number of settlements where one could be appointed as prikazchik was obviously increasing at a far slower pace. There were 10 settlements in 1666 , in $1680-12,{ }^{86}$ and by $1698-15 .{ }^{87}$

There was more than a twofold increase in the number of local elite servitors. This increase seems to have contributed to the rise of tensions between officials and other residents of the Verkhotur'e settlements. The data for Irbitskaia sloboda show that 
between 1680 and 1699, the average length of service as prikazchik slightly decreased. Even though most appointments continued to last a year or slightly more, the number of long appointments (about two years) decreased, while the number of shorter ones (several months) increased. The average term of office was about nine months, in comparison to one year and seven months between 1660 and $1679 .{ }^{88}$ The data from the entitlement books for the $1690 \mathrm{~s}^{89}$ show that only few deti boiarskie managed to serve as prikazchiki on a regular basis (Ivan and Fëdor Tomilov were among them). ${ }^{90}$ For most of them, records such as the following are characteristic: "He was not remunerated (zhalovan'ia emu ne dovelos') till (or from) March 1, because he was a prikazchik in ... sloboda." This means that after a shift as a prikazchik, a syn boiarskii was not appointed to another settlement and usually had to engage in some less profitable service.

According to testimonies by deti boiarskie in the case against Belosludskaia sloboda prikazchik Maksim Chernyshov, who was charged with extortion, appointments to the post of prikazchik depended on a system of bribes to Governor Dmitrii Protas'ev. An appointment to the largest settlement, Nev'ianskaia sloboda, cost 120 roubles, the fair centre Irbitskaia sloboda - 100 roubles, large Aramashevskaia or Kamyshlovskaia sloboda - from 80 to 90 roubles, Belosludskaia - 80 roubles, remote Beloiarskaia - 30 roubles, etc. ${ }^{91}$ It is reasonable to believe that this practice existed before Protas'ev's term of office (1695 -1698). The need to compensate for these preliminary "investments," added to the fact that prikazchiki spent less time than in previous decades on appointments that were growing shorter, probably stimulated them to be very proactive in their search for 'gifts' from the population under their control.

For these or other reasons, the 1690 s are marked by numerous conflicts between deti boiarskie and the bulk of the population, with investigations against specific prikazchiki, and by two petitions signed by peasants of the whole district complaining against the oppression from the deti boiarskie residing in the settlements. The second petition requested the expulsion of the deti boiarskie from peasant settlements. Simultaneously belomestnye Cossacks were fighting to be withdrawn from subordination to prikazchiki. ${ }^{92}$ Anna Joukovskaia's research on the materials from Sevsk district demonstrates a somewhat similar situation - simultaneous growth in the number of clerks and intensification of the local population's discontent towards them..$^{93}$

Let us now look in the sources of that impetuous time for some data on the Tomilovs. We have already cited the data about Ivan Tomilov drawn from a major investigation (sysk) into abuse by Irbitskaia sloboda prikazchiki in 1698 and 1699. The investigation materials tell us that in 1698, Dementii Vagan, a peasant of Irbitskaia sloboda, filed a petition to the Siberian Chancellery against persecutions (izgoni) and offences (obidy) committed by prikazchiki. The petition was accompanied by a list of the names of 121 peasants who had run away from the settlement since the previous census, held in $1680 .{ }^{94}$ On instruction from Moscow, though with a certain delay, ${ }^{95}$ an investigation was conducted in February and March 1699. Representatives of all categories of the population of Irbitskaia sloboda and neighbouring Nitsynskaia and Belosludskaia slobody were interrogated. The main objective of syn boiarskii Alexei Tyrkov and clerk Vasilii Danilov was to find out the reasons that pushed the people mentioned in Dementii Vagan's list to run away from the settlement. The materials of the investigation are rather tangled; our calculations are somewhat different from those made by Viktor Shunkov. Contrary to Shunkov's assertions, the list filed with the Siberian Chancellery seems to exaggerate the scale of the exodus. In addition to two peasants who still resided in the settlement and two peasants 
who had died natural deaths, all reported by Shunkov, the investigation found that the list included 15 peasants who had died or run away before the Verkhotur'e census of 1680 ${ }^{96}$ and six (instead of three) dead peasants. ${ }^{97}$ Moreover, the peasants of Irbitskaia sloboda were not able to account for 14 missing persons whose names appeared on Dementii Vagan's list. ${ }^{98}$ However, in general, Viktor Shunkov's calculation adequately reflects the results of the investigation: the number of flights was high, abuses (napadki) by prikazchiki were predominant among the immediate causes of flights (the second cause being "skudost'," i.e., indigence). It should be added that the peasants had no reasons to asperse Ivan Tomilov. At the moment the investigation was launched, he had already become a syn boiarskii in Tobol'sk and could hardly be punished or re-appointed as prikazchik.

The interrogated mentioned six cases of persecution in which Ivan Tomilov was involved. Like many other deti boiarskie, Tomilov often harried the peasants, sometimes even without waiting to be appointed as prikazchik. In the following, typical, example, he even appears persecuting a peasant jointly with another syn boiarskii: "The previous year [7]201, Irbitskaia sloboda was managed by the uninitiated syn boiarskii Mikhailo Miklailov syn, Bibikov. During his rule, obrochnyi peasant (liable to pay quitrent - obrok) Timoshka Shelomentsov from Irbitskaia sloboda ran away from persecution by prikazchiki Vasilii Protopopov and Ivan Tomilov to settlements of Tobol'sk district. Ivan Tomilov had kept Timoshka working for him during the harvest campaign ( $\mathrm{v}$ stradnoe vremia), made him dig a cellar for him, and taken a bull from him, and Vasilii Protopopov also took a bull from him. Ivan and Vasil' got the bulls through force, not as a remuneration (svoimi napadkami, a ne ot del). This is how Timoshka got impoverished." ${ }^{99}$ Moreover, the majority of peasants who had run away because of Tomilov's wrongdoing had at the same time suffered at the hands of other deti boiarskie (four out of six).

30 Nevertheless, the reviewed data show that Ivan was not the cruellest prikazchik. The above-mentioned Mikhail Bibikov and Vasilii Protopopov were each involved in 13 incidents. ${ }^{100}$ However, the circumstances were such that Ivan Tomilov and his brother were the objects of a series of investigations that allow us to do a rather vivid and comprehensive "portrait" of a Siberian syn boiarskii in the early years of Peter's rule. While almost every element of this portrait is typical (i.e., corresponding to gathered historiographical data), as a whole it turns out to be rather extraordinary.

\section{Conflict with Governor Ivan Eliseevich Tsykler}

From December 1693 until the end of January 1695 (with an absence due to a trip to Tobol 'sk in June-July 1694), Ivan Tomilov served as a prikazchik in Irbitskaia sloboda. From September 1694 to January 1695, an investigation against him was launched on the charge that he had murdered settlement resident Kseniia Agapitova. Her last name suggests that she had been married to a peasant of Nev'ianskaia sloboda, ${ }^{101}$ but after her husband's death she moved to Irbitskaia sloboda, where her brother, belomestnyi Cossack Mikita Maliugin, lived (their kinship is repeatedly reported in the case). The first documents of the case have not survived. Kseniia's son Aleksei's second petition, filed on February 8, 1695, reports that in 1692-1693, Ivan Tomilov took a fancy for the Agapitovs' bull. For this reason, the prikazchik "began to harass our mother and ask her to give him the bull." 102 Kseniia refused ("she wanted to sell it for her soul to be commemorated after 
her death"). Then he decided to impose a monetary quitrent on the family, while the Agapitovs had not payed tiaglo tax.

During the harvest campaign I, your orphan, with my brother and my sister, was in the meadow harvesting. Our mother was in our house. He, Ivan, knew that I, your orphan, had left the house with my brother and my sister. So he sent Ondriushka Semënov, janitor (komornik), to our mother in order to take her to his homestead, where he, Ivan, asked our mother to give him that bull, and promised to lift the imposed tax in exchange for the bull... and our mother refused to give him the bull. As she was leaving his house, he, Ivan, came out of the room alone and kicked her off the porch, and thus killed her (Ivan vyshed iz gornicy odin mat' nashu s kryltsa tolknul i tem ee ubil). After that our mother continued to live for three hours, but could not speak, and then she died. And the priests of Irbitskaia sloboda were afraid to bury her due to his, Ivan's, murder, and it was long before they buried her. And he, Ivan, is a known murderer. In Verkhotur'e, in the governor's office (prikaznaia polata), he similarly kicked pod'iachii Ivan Permiakov off the porch with the intention of killing him. And he, Ivan, personally beats many peasants with whatever he has under his hands. ${ }^{103}$

During the collection of oral testimony (rasprosnye rechi) preceding the investigation, most residents of the settlement said that they were absent and had not seen anything. ${ }^{104}$ However, janitor Andrei Semënov syn Lavelin, referred to in the petition, gave evidence that generally confirmed Aleksei Agapitov's statements. ${ }^{105}$ Peasant Afanasii Dolgushin also confirmed having seen Ivan Tomilov kick Kseniia off the porch. ${ }^{106}$

A memo on the summons of the Tomilov brothers, belomestnyi Cossack Mikita Maliugin, peasants Andrei Lavelin, Afanasii Dolgushin and Ivan Kocherga to Verkhotur'e was written in January (the surviving copy is not dated). ${ }^{107}$ The listed persons were evidently summoned as witnesses to the murder of Kseniia Agapitova; still, the governor's desire to see Fëdor Tomilov as well implies that he had some questions to ask him too. Perhaps they were related to the accusation of participation in the theft of Ides Izbrandt's property (zhivoty). The draft of another memo (which was probably never sent) prescribed to deliver Fëdor and Ivan Tomilov to Verkhotur'e by January 22, 1695, "in relation to a report by a Chusovskaia sloboda peasant, Kozemka Nikitin syn Sulei, about the stolen property of envoy Elizarii Izbrandt." ${ }^{108}$ The theft does not seem to be a major one. Ides Izbrandt's embassy did pass Utkinskaia and Aramashevskaia slobody on its way to China in the first half of June 1692, when Fëdor Tomilov was the prikazchik of one of these settlements. However, the records of both the head of the embassy and his assistant Adam Brandt only describe well maintained fields and abundant supplies. ${ }^{109}$ The issue of the embassy's property is absent from other known documents.

Ivan Tomilov was brought to justice in Verkhotur'e on January 28, $1695 .{ }^{110}$ During interrogation on January 30, he admitted that on August 24, he sent a janitor for Aleksei Agapitov in order to impose quitrent on the latter. However, he had not ordered the janitor to bring Kseniia along. "[...] she left Ivan's house with her brother Mikitka Maliugin." Ivan did not know what happened to her next, but she "died in Aleshka's house, with sacraments" ( $\mathrm{z}$ darami) ${ }^{111} \mathrm{He}$ refuted the evidence against him, pleading in defence that the janitor had been caned for incorrect performance of the order and that Afanasii Dolgushin was taking revenge for not having been able to contest a promissory note (kabala) that, Afanasii claimed, was forged ${ }^{112} \mathrm{He}$ also mentioned the people present in the izba with him as defence witnesses - according to Ivan's oral petition, they had already been interrogated by that time, apparently several days before. Indeed, priest Parfenii Udimtsov, peasants Ganka Konovalov and Ivashka Fomin asserted 
that the prikazchik had not beaten Kseniia in their presence. ${ }^{113}$ It was impossible to interrogate Kseniia's brother Mikita Maliugin because he had gone to fish on the Iset ${ }^{\prime 114}$; the case also lacks the testimony of Vasilii Protopopov, another witness cited by Tomilov.

Nevertheless, by that time the case had taken a new direction. At the moment of Ivan Tomilov's arrest (it took place in Belosudskaia sloboda in the homestead of belomestnyi Cossack Martyn Dement'ev), distillation equipment was found in the homestead: "About 10 vedro ${ }^{115}$ of vodka in two barrels (bochkakh), and around 60 vedro of home brew (vinnaia braga) or more in two tanks." The vodka was made for Ivan by his man (chelovek ego), Stenka and peasant Fedotko Omelianov called Lovchivoi. In the mirskoi dvor (homestead used for the community's needs) of Irbitskaia sloboda, where prikazchiki lived, two more barrels with 10 vedro of vodka were found. ${ }^{116}$ Practically right after Ivan Tomilov's was brought to justice in Verkhotur'e, Irbit peasants (resolution [pometa] dated January 29) and belomestnye Cossacks (resolution dated February 1) filed their petitions. The first petition listed the following sins committed by the prikazchik: he inflicted losses (nalogi chinil) and took big bribes (posuly) in exchange for exoneration from tiaglo tax, changed sworn men (tseloval'niki) in exchange for bribes, detained janitors. "He tortured Ofonka Novinov and his son in the courthouse (v sudnoi izbe) for a long time. He took his possessions and let Ofonka move to the settlements of Tobol'sk on the Tobol with his wife and children" (peasants cited this episode again in 1699); "and during haymaking time your orphans mowed and raked for Ivan, every single one of us. And those who would not mow and rake had to give him a cartload of hay or more. And when we brought to your treasury our annual tax in grain (khlebnoi godovoi obrok), Ivan had from us an osmina ${ }^{117}$ of rye, an osmina of oat, and if someone did not bring an osmina of rye and an osmina of oat, he would not let their tax in grain be accepted in your treasury."118

The Cossacks complained that Ivan Tomilov frequently went to the villages and took two Cossacks with him, "and received money for the third one" (a za tret'ego imal dengi). He ordered to guard his homestead, but the guard was to be posted on the porch at night, and "forbade anyone to live in the courthouse" (a v sudnoi izbe zhit' ne velel). Ivan Tomilov gave to desiatnik Fëdor Ignat'ev a memo to go to the villages where he would send him, and immediately exile peasants. If peasants did not obey, Cossacks were obliged to beat them to blood, and if someone came back safe, he would be punished with a five-rouble fine and caned. The prikazchik also held them in his homestead for a week to make them work. If Cossacks failed to hand over an alleged debtor to Tomilov, he "would beat [them] with his hands, hatchet hammer and canes to death." 119

On February 11, 1695, several Irbit peasants informed the governor's office that Ivan Tomilov was selling the homesteads of fugitive peasants (specific examples were cited) and misappropriated fugitive peasants' grain. ${ }^{120}$

The case contains investigation documents related only to one issue, i.e., whether Ivan Tomilov had sold fugitive peasants' homesteads. The prikazchik's defence was quite successful. ${ }^{121}$ Nevertheless, upon review of extracts from relevant documents (vypisi), the governor's office considered that the prikazchik had indeed violated the governor's instructions. Moreover, there was direct proof of distillation. On February 16, the governor took the decision to cane the brothers and to continue the investigation in the settlements. In response, Ivan Tomilov (perhaps, the humiliation of the punishment played some role) made accusations of lese-majesty (gosudarevo strashnoe slovo), just like his elder brother in Aramashevskaia sloboda twenty years earlier. As for Fëdor, he 
declared that he knew of some sins of the governor and was afraid for his life. As a result, Ivan was sent to Moscow, and Fëdor to Tobol'sk. ${ }^{122}$ The recourse to accusations of lesemajesty was very hazardous. Perhaps Tsykler did not venture to imprison Fëdor because he was afraid of drawing suspicion on his political loyalty: even though Ivan Eliseevich had left tsarevna Sofia and taken Peter's side in time and got promoted, he could not count on the tsar's absolute trust. Along with a report to Moscow, the governor sent a petition by Verkhotur'e deti boiarskie, informing that the latter did not know of any crime of lese-majesty committed by the governor and described the case initiated by Tomilov as "fabricated" (zateinoe), asking to save them from devastation (which, probably, would be incurred by the investigation). ${ }^{123}$

The petition was written on behalf of 18 persons (not all of them signed personally). The document was most likely initiated by Tsykler. However, it was hardly possible to force deti boiarskie to sign a petition if they absolutely disagreed with its content. This suggestion is supported, in particular, by the fact that one of the signatories (Ivan Albychev) subsequently initiated the arrest of Fëdor Tomilov when the latter secretly travelled around settlements without informing Verkhotur'e authorities. In this regard, it is remarkable that numerous deti boiarskie, who had actively interacted with Tomilov in their duties and beyond, were among the signatories of the petition. The first to "put his hand" to the petition was the above-mentioned Mikhail Bibikov. It was him who was appointed to replace Ivan Tomilov in Irbitskaia sloboda. He also served there as prikazchik immediately before Tomilov and several times before that. They both oppressed several peasants. Il'ia Iartsov, Il'ia Budakov and Tikhon Golovkov had been serving in Irbitskaia sloboda too, while Budakov and Golovkov had homesteads there. ${ }^{124}$ Grigorii Zagurskii, who at that moment was running Beloiarskaia sloboda - another settlement well known to Ivan Tomilov - signed for himself and for Ivan Iakubovskii. ${ }^{125}$ Stepan Golovkov, who also signed the document, had earlier run this settlement. It was not his first term there and, evidently, he was not an example of unselfishness: peasants complained about him. ${ }^{126}$ Ivan Zagurskii, that same person who once calmed a raging Fëdor Tomilov down in Aramashevskaia sloboda, also signed the petition. The governor suspended the investigation until the case against him was over. In March, he ordered all the Tomilovs' property to be sealed: Ivan Tomilov's in Irbitskaia and Beloiarskaia settlements, Fëdor's in Aramashevskaia and Nev'ianskaia.

Most of Ivan Tomilov's inventoried belongings in Irbitskaia sloboda were located in two trunks, ${ }^{127}$ except for weapons, skins and large copperware. There were a few objects of prestigious consumption among them: a sugarloaf, a knife and small forks, a steel Persian cup, two big Kizinbatsian carpets, a silver funnel. His wardrobe comprised casual, worn clothes and an abundance of fur clothing that was quite natural for Siberia (simple knitted stockings, a small buttonless squirrel coat covered with kitaika, a worn sable hat with a green woollen cloth top, etc.). ${ }^{128}$ Most of the weapons found were old: "five old arquebuses (pishchali)," "an old brigandine with an inner layer of red woollen cloth, two simple sabres, an ax-hammer with a hammer face, a pair of pistols with holsters." ${ }^{129}$ However, this personal collection of arms would probably seem considerable for many provincial deti boiarskie in European Russia. ${ }^{130}$ Ivan Tomilov was apparently no bibliophile: there were only a manuscript Ulozhenie (the Law Code of 1649), two copies of a Psalter with a sequence of services (sledovanie), and a teaching Psalter (uchebnaia). However, the data underestimate Ivan Tomilov's level of consumption: the confiscation of property took place about one month after the conflict between Ivan Tomilov and the 
governor, so Tsykler's subsequent assertion that the most valuable property had been hidden by priest Parfenii Udimtsov ${ }^{131}$ seems to correspond to the facts.

On the other hand, it was far more difficult to hide the cattle, grain and homesteads. According to the lists established at the moment of property restitution, Ivan Tomilov kept six geldings, two mares, one stallion, three colts, seven cows, "three heifers, six small two-year-old heads of cattle" in the houses of peasants, who were in charge of feeding the cattle. He also possessed grain: 30 chetvert' of wheat, 100 chetvert' of rye, 10 chetvert' of oat and 110 poods ${ }^{132}$ of salt. ${ }^{133}$ In Beloiarskaia sloboda, Ivan Tomilov had in his barn " 166 poods of rye, 150 poods of wheat, 47 poods of barley, 77 poods of oat." 134 Moreover, according to an orderfrom the Siberian Chancellery in relation to the case, Ivan Tomilov had three houses in Irbitskaia sloboda with six cellars under them, two homesteads received in lieu of debts, three seni, three shops, four stores in a market hall (gostinyi dvor), two barns (according to the owner's evidence). The description sent by Tsykler omits two shops, one cellar and two "debt" homesteads, while it reports 15 huts. 135

The inventory of Fëdor Tomilov's property in Aramashevskaia sloboda made on March 18 produces a similar picture. ${ }^{136}$ There too, some apparently expensive and prestigious objects could be found: "A white kaftan covered with azure laudan (silk fabric with patterns), a white kaftan covered with yellow taffeta and golden braid," "a black German hat." However, most of the listed objects are quite ordinary. Books are not recorded at all, while "a small box with various letters" was taken to Verkhotur'e together with the distillation equipment (as we mentioned earlier, it was seized along with a considerable amount of alcoholic beverages). "Two letters to the hierarch" (dva pisma k arkhiereiskomu litsu) were found during the property restitution procedure.

In this case, the facts of the property sale are reflected immediately prior to the inventory. The residents reported that Fëdor Zav'ialov, a musketeer's son, came to the settlement on three horses and bought objects from Fëdor Tomilov's wife. Different people, whose names the peasants did not remember, bought grain from the barns of the arrested syn boiarskii. ${ }^{137}$ Despite his junior status, Zav'ialov was only three years younger than Fëdor Tomilov. Zav'ialov's father and grandfather served as musketeers with Tomila Nefed'ev. According to the censuses of 1666 and 1669, both Fëdor Zav'ialov and Fëdor Tomilov lived in Verkhotur'e, so they could have played together in their childhood. ${ }^{138}$

The following episode is rather surprising: uninitiated syn boiarskii Prokopii Buzheninov is reported to have lent 10 roubles to Fëdor Tomilov the day before, with two kaftans as security. This fact is confirmed by church elder (starosta) Feofan Lazarev: at first Fëdor turned to him, but Feofan refused; then Fëdor Tomilov borrowed money from Buzheninov (the men were in his house). The church elder had been a victim of an aggression by the Tomilov brothers in $1674 .{ }^{139}$ Even if he was not their in-law, as a resident of the central settlement of Aramashevskaia sloboda, he regularly interacted with them on different matters, and, as we can see, could behave quite independently. Fëdor Tomilov's grain stocks were much more impressive than those of his brother: 289 chetvert' of rye, 10 chetvert' of rye flour, 17 chetvert' of barley in Aramashevskaia sloboda, and 170 chetvert' of rye, 20 chetvert' of barley in Nev'ianskaia sloboda. ${ }^{140}$

47 In Tobol'sk, Fëdor Tomilov apparently managed to get permission for a trip to Verkhotur 'e district, gathered guarantors and even secured his own and his brother's initiation into 
the deti boiarskie of Tobol'sk as late as May $1695 .{ }^{141}$ Connections with local servitors and/ or clerks are very likely to have contributed to his success. Although no direct indications are available, one can surmise that the Tomilovs had reasons enough to make some useful connections in Tobol'sk. As mentioned above, Fëdor Tomilov's original initiation took place following a report (otpiska) from Tobol'sk, while his first appointment before the initiation was a business trip to Tobol'sk. In 1686-1687, Beloiarskaia sloboda, neighbouring Aramil'skaia and Novaia Kamyshevskaia slobody, which depended on Tobol 'sk, could not be founded without communication with representatives of "the Siberian capital." Perhaps, the fact that Andrei Fëdorovich Naryshkin, governor of Tobol'sk and a relative of the tsar's mother, did not harbour warm feelings towards the former partisan of Tsarevna Sofia played a certain role. Tomilov's promise to seek the transfer of Beloiarskaia sloboda under the jurisdiction of Tobol'sk must have been an important reason for Naryshkin to help the Tomilovs.

Ivan Tomilov's efforts paid off in Moscow (they must have been well-prepared beforehand). The draft of Tsykler's 1695 report to Moscow (the month is not recorded) reads that Grigorii Zagurskii, prikazchik of Beloiarskaia sloboda, wrote to Verkhotur'e that prikazchiki of Aramil'skaia sloboda, syn boiarskii of Tobol'sk "Ivan Polozov and a colleague (s tovaryshchem)" came to him "to get a copy of the dannaia (document defining the limits of the settlement) and to set boundaries and landmarks on the disputed land in order to avoid further dispute between the peasants of Aramil'skaia and Beloiarskaia settlements." At the same time, Verkhotur'e syn boiarskii Ivan Tomilov, "who was going to Tobol'sk with [the Sovereign's] orders, arrived in the settlement. He gave Ivan Polozov his signed testimony (skaska) stating that Beloiarskaia sloboda was built on the territory allocated for the Aramil'skaia and Kamyshevskaia settlements of Tobol'sk district, and not Verkhotur'e district. In order to set those boundaries and landmarks, Ivan Tomilov went with Ivan Polozov to the village of Brusnianskaia, located six versts ${ }^{142}$ from Beloiarskaia sloboda. Ivan Tomilov went around the fields, branded trees with an X (grani)' dug pits and placed pillars in them and scattered coal on new places and not on the former allotment (po novym mestam a ne po prezhnemu otvodu). And the grain that had been sewn by the peasants of Beloiarskaia sloboda became their [the peasants of Aramilskaia sloboda] allotment together with the meadows of the peasants [of Beloiarskaia sloboda] (A kotorye de naseiannye khleby $\mathrm{u}$ beloiarskikh krestian byli, $i$ te khleby i sennye pokosy stali u nikh $v$ otvode). Then they went to Beloiarskaia sloboda and injured and beat peasants to death. And, sirs, Beloiarskaia sloboda was built in the past years [7]194 and [7]195, under your orders and the ones of boiarin and governor Grigorii Filimonovich Naryshkin [...]." ${ }^{143}$

Simultaneously - not without the help of Ivan Euplov, an in-law priest of Nev'ianskaia sloboda, Fëdor Tomilov arranged with Siberian metropolitan Ignatii to declare the sealed homesteads and buildings as a donation to the church made during the metropolitan's stay at Irbit fair in January 1695. ${ }^{144}$ The grain kept in those homesteads was supposed to be declared the prelate's property. Tomilov partly succeeded: having obtained a permission to visit his home from the governor of Tobol'sk, he arrived at the house of the priest of Nev'ianskaia sloboda, Ivan Euplov, in early May. After some travelling about, he was arrested in Nitsynskaia sloboda on May 9 and turned over to the Verkhotur'e authorities. During his absence, on May 12, Ivan Euplov managed to have the seals removed from Ivan Tomilov's barn in Nev'ianskaia sloboda: he read the metropolitan's order out loud to the prikazchik, but did not let him copy it. The fact that Nev'ianskaia 
sloboda prikazchik Matvei Iakubov (Iakubovskii) did not ask for the governor's permission shows a certain indulgence on his part. As soon as the news that the seals had been removed from the barn reached Verkhotur'e (on May 16), orders confirming the interdiction to give the sealed property to anyone, including representatives of the Metropolitan's office (archiereiskii dom), were sent to the settlements. ${ }^{145}$ On July 3, in response to Ivan Tomilov's petition, the Siberian Chancellery ordered the release of Fëdor and allowed him to go to Tobol'sk and have the seals removed from the Tomilovs' property and the property restituted to the brothers against receipt (s rospiskoiu). On August 16, 1695, a memo was written on the basis of this order in Tobol'sk. ${ }^{146}$ In the second half of September, the property was returned to the Tomilovs. ${ }^{147}$ Shortly before that, metropolitan Ignatii, who apparently considered the episode as an occasion to demonstrate his resolution in defending the property interests of the church against the secular authorities, ${ }^{148}$ tried to make Tsykler transfer the stocks, which allegedly belonged to the prelate, from Ivan Tomilov's house. The governor refused and was excommunicated. In his report dated October 30, sent to the governor of Tobol'sk and to the Siberian Chancellery, Tsykler argued that the presence of church property in Ivan Tomilov's house was a "deliberate lie on the part of the priest of Nev'ianskaia sloboda Ivan Euplov" (vymyshlennaia zateinaia lozh' Nev'ianskoi slobody popa Ivana Euplova). In order to prove it, he referred to a letter (gramota) "addressed to the hierarch (na arkhiereiskoe imianovanie) and begging to forgive his sin, that he, priest Ivan, declared without the hierarch's order (bez evo arkhiereiskogo ukazu) that the salt in Ivan Tomilov's cellars belonged to the hierarch." ${ }^{149}$ The governor's statements are confirmed by the fact that in Moscow, Ivan Tomilov begged to transfer his shops to the Sovereign, without even mentioning his "obligations" towards the metropolitan.

Shortly after that, Tsykler was removed from the governor's office. A gramota of the Siberian Chancellery dated December 1695 concerning metropolitan Ignatii's claims was addressed to Dmitrei Petrovich Protas'ev. It prescribed giving the metropolitan "household grain stocks and various food supplies" (domovye khlebnye zapasy i stolovye obikhody), while the buildings allegedly conceded to the metropolitan had to be transferred to the treasury. The gramota gave the following reason: "In virtue of our, the Great Sovereign's, decree and the Ulozhenie, servitors and people of any rank are not allowed to give any homesteads, villages or plots of land to monasteries or churches." ${ }^{150}$

Under Governor Protas'ev, the investigation went on for some time, headed by the Tomilovs' old acquaintance, now a colleague, Ivan Polozov, who was sent from Tobol'sk. Not surprisingly, his investigatory actions did not harm the brothers. Until 1699, the Tomilovs tried to take the people who inventoried their property to court on charges of "robbery." In his final petition, Ivan Tomilov renounced his claims against former colleagues and, perhaps not without pleasure, referred to Tsykler, who had been executed on charges of conspiracy against Peter I, as Ivashka. ${ }^{151}$ We may suppose that the disregard for Tsykler's opinion in the Tomilov affair was one the factors causing his dissatisfaction with young Peter's rule and giving rise to his seditious talks about changing the ruler ${ }^{152} \ldots$ Thus, the serious abuse revealed by Tsykler remained unpunished despite his resolution. Besides, the punishment may not have been too severe. The Tomilov brothers' determination to evade it was probably due to their fear that the development of events would threaten their material well-being; in addition, available data suggest so far that fear of humiliation was also very important. Ivan and Fëdor Tomilov skilfully played with the antagonism between secular authorities (addressing both Tobol'sk and Moscow was a 
traditional technique for the dissatisfied) and ecclesiastic superiors (appealing to the metropolitan was not that typical for Verkhotur'e district) and used their local kinship and friendship networks, thereby demonstrating an astonishing talent for coming through without a scratch. Neither recourse to such a dangerous instrument as crime of lese-majesty nor a certain lack of coordination could harm them. Instead, the brothers achieved status promotion even though they did not manage to transfer Beloiarskaia sloboda to Tobol'sk district that time.

\section{Service in Tobol'sk}

In August 1701, Ivan Tomilov filed a petition to the Siberian Chancellery. After listing his merits (transfer of homesteads, barns and cellars in Irbitskaia sloboda - allegedly 100 roubles worth - to the state, construction of Beloiarskaia sloboda by his own means), he asked to be appointed to "finish construction" of Beloiarskaia sloboda (which had to be first transferred under the jurisdiction of Tobol'sk) and for his son Vasilii to be appointed to Aramil'skaia sloboda. He also suggested making Vasilii a captain, since Aramil'skaia sloboda was inhabited by dragoons. By that time, along with the documents of the case initiated by Tsykler, the documents of the above-mentioned investigation of 1698-1699 on prikazchiki abuse in Irbitskaia sloboda, where Ivan Tomilov was repeatedly reported, had already arrived to the Siberian Chancellery. As for Vasilii (about 27 years old at the time), he did not have any serious military experience and had not even been recruited into service. However, a summary of the documents related to the facts mentioned by Tomilov (prikaznie vypisi) was established in such a way as to confirm the words of the petitioner. It is also interesting that there remained exactly one vacant dragoon captain post. D'iak Andrei Vinius "and colleagues" granted the petition. ${ }^{153}$ As we can see, Ivan Tomilov continued to build his, and his son's, careers by reinforcing his position within a certain territory. The location of this territory, in an area of contact with nomads and with a large proportion of dragoons in the population of local settlements, ${ }^{154}$ made it logical to seek promotion into dragoon officers' rank. That step brought about a status raise without dramatically changing the lifestyle typical of the prikazchiki of the southern borderland: their subordinates were the same peasants (promoted to dragoons by entire settlements). Service in the dragoons was similar to the traditional service of belomestnye Cossacks but with additional elements of European drill training. However, regular participation in military operations represented an unquestionable disadvantage in this type of service. ${ }^{155}$

According to the list of servitors, fortifications and arms (perechnevaia rospis') of Tobol 'sk district composed in 1702, the decision of the Siberian Chancellery in relation to Ivan Tomilov's petition was not exactly complied with. Tomilov was appointed to Murzinskaia sloboda instead of Beloiarskaia sloboda. ${ }^{156}$ However, his interests were hardly infringed upon. Murzinskaia sloboda was close to Beloiarskaia sloboda and of comparable size. Ivan's son Vasilii did become a captain in Aramil'skaia sloboda. ${ }^{157}$ Fëdor Tomilov is reported as the prikazchik of Blagoveshchenskaia and Rudnaia slobody, ${ }^{158}$ located not far from Nev'ianskaia, Nitsynskaia and Irbitskaia slobody, which belonged to Verkhotur'e district.

In 1704, Ivan Tomilov was registered among deti boiarskie with an entitlement of seven roubles, while 58-year-old Fëdor, discharged because of his senior age, was replaced in service by his son Pimen, ${ }^{159}$ 35-37 years old at the time. ${ }^{160}$ In 1705, Tobol'sk governors, 
Princes Mikhail Iakovlevich and Aleksei Mikhailovich Cherkasskii carried out numerous initiations and increased some entitlements by assigning vacant ones. Pimen Fëdorovich Tomilov received an entitlement which earlier belonged to Aleksei Vykhodtsev (its natural part consisted of seven old kazennaia chetvert' ( 4,5 poods) of rye and oat and two poods of salt), while his father's former entitlement was "transferred" to his brother Fëdor Fëdorovich Tomilov. ${ }^{161}$ The third brother, newly initiated Venedikt Fëdorovich Tomilov, also received an entitlement of the same level which earlier belonged to Aleksei Cherkasov. ${ }^{162}$. Ivan Pankrat'evich Tomilov, the oldest family member in service, was enrolled in the Tobol'sk dvoriane, though his entitlement was reduced to one rouble. ${ }^{163}$

Newly initiated deti boiarskie immediately found themselves in a rather small group of servitors (43 out of 320$)^{164}$ appointed to settlements. Hence, in Tobol'sk, the Tomilovs remained in the same prikazchik niche as in Verkhotur'e, even though the incomparably higher number of deti boiarskie may have contributed to tougher competition. The same year - 1705, Pimen Tomilov ran Novopyshminskaia sloboda, his brother Fëdor, Blagoveshchenskaia and Rudnaia slobody. ${ }^{165}$ In 1707 , we find a Fëdor Tomilov in the list of Tobol'sk servitors "in service and on missions" (na sluzhbakh i posylkakh), (still?) as prikazchik of Blagoveshchenskaia and Rudnaia slobody. ${ }^{166}$

Fëdor Pankrat'evich Tomilov's third son, Venedikt, served as prikazchik of Novopyshminskaia sloboda in 1709, not far from Beloiarskaia sloboda, itself run by his uncle Ivan Tomilov. ${ }^{167}$

In 1707, Vasilii Ivanovich Tomilov served in Shadrinskaia sloboda, where he, together with the local administration and another captain, imposed additional taxation on peasants. ${ }^{168} \mathrm{He}$ also participated in military operations against nomads (which actually was the principal function of his regiment). On August 2, 1709, together with Captain Ivan Butkeev he fought Karakalpaks off the Tsarevo gorodishche (future city of Kurgan). 169 On September 5, Vasilii Tomilov (again with Ivan Butkeev and Lieutenant Colonels Stepan Tekut'ev and Fedot Matigorov) fought off a Bashkir incursion on Ikovskaia sloboda and had his left leg injured; ten days later he was back repelling another, less significant, Bashkir incursion on Ikovskaia sloboda. ${ }^{170}$

We learn from the 1710 census that, by that time, Ivan Tomilov had moved closer to his son - to Shadrinskaia sloboda, where he resided in a homestead belonging to the local church (tserkovnyi dvor). He was 56 years old and lived with his young wife Melan'ia (22 years old), sons Semën (20 years old, already recruited into deti boiarskie), Ivan (16 years old), Iakov (15 years old), Prokopii (6 years old) and one-year-old daughter Nadezhda. The census also reports house serfs (dvorovye) of Russian, Kalmyk, Ostiak (Khanty) and Bashkir nationalities (porody): four men (two of them married), seven women, two minor children and one 15-year-old foster girl (pokormlinnitsa). Ivan continued his service; in particular, in June of the same year, he took the census of several settlements of Tobol'sk district, including the homesteads of his nephews. ${ }^{171}$ The captain of Shadrinskaia company, 35-year-old Vasilii Ivanovich Tomilov lived in the same settlement in the homestead of scribe (pischik) Filipp Alekseevich Popov. The captain's family consisted of his wife Ovdot'ia (27 years old), son Iakov ( 3 years old), daughters Anna (6 years old) and Vasilisa (5 years old). He also had serfs (Russians, Kalmyks, Bashkirs and Ostiaks): two men, three women, three children and one foster girl (13 years old). ${ }^{172}$

Fëdor Tomilov seems to have died before the census of 1710. His elder son Pimen (43 years old) owned a homestead in Novopyshminskaia sloboda. He lived with his wife 
Matrëna Vasil'evna (40 years old), his daughter Stepanida (17 years old) and her husband - syn boiarskii of Tobol'sk Fëdor Mikhailovich Ievlev (20 years old). Other residents included Pimen's younger daughter Irina (13 years old), three house serf girls, a 13-yearold house serf boy (chelovek) and a migrant wageworker (stroshnoi prishloi chelovek). ${ }^{173}$ Pimen's homestead neighboured upon that of his brother, syn boiarskii of Tobol'sk Ivan Fëdorovich Tomilov ( 35 years old), residing with his wife Mar'ia Iakovlevna (30 years old) and numerous offsprings: sons Pëtr (13 years old), Savva (10 years old), Aleksei (4 years old), daughters Mar'ia (9 years old), Praskov'ia (2 years old) and six-month-old Varvara ${ }^{174}$ . Fëdor's third son, Venedikt (30 years old) was also enlisted as syn boiarskii of Tobol'sk. His homestead was located in Kalinovskaia sloboda, relatively close to Novopyshminskaia sloboda. The other residents of the homestead were Venedikt's wife Domna Vasil'evna (30 years old), six-month-old sons Pavel and Stepan, daughters Irina Leont'eva, 15 years old (apparently adopted), and Tatiana (3 years old). The family of a migrant (prishlyi chelovek) and two serf girls resided with them. ${ }^{175}$ It can be argued that the divergence of Ivan and Fëdor Tomilov's career trajectories, which had been already noticeable in the Verkhotur'e period, deepened. Fëdor's sons continued their service as deti boiarskie of Tobol'sk. The high number of people at their service can be considered as an important sign of social advancement; nevertheless, both in status and in number of serfs, they were inferior to Ivan Pankrat'evich and Vasilii Ivanovich Tomilov. They also lived in different "areas." While Ivan Pankrat'evich Tomilov and his son lived on the border with the steppe, the sons of Fëdor Pankrat'evich Tomilov preferred residing in several settlements on the Pyshma river, relatively far from the steppe.

61 The 1720 census book records show further reinforcement of the service positions of Ivan Tomilov's descendants (Ivan Tomilov seems to have died by that time). The homestead of Lieutenant Colonel (podpolkovnik) Vasilii Ivanovich Tomilov is registred in Ikovskii stanets on the Tobol river. In this rank he was already recorded in 1716 as comissar of Tebeniatskaia sloboda. ${ }^{176}$ The residents of the homestead include children Iakov and Fedot, 13 and 7 years old respectively, and three serfs of Russian nationality, two of them minors. Next to it was located the homestead of 29-year-old captain Ivan Ivanovich Tomilov, ${ }^{177}$ who had an 11-year-old serf of Bashkir nationality. ${ }^{178}$

62 As for the lives of Fëdor Pankrat'evich Tomilov's descendents at the time, we know that in December 1721, Venedikt Tomilov took the post of court comissar for Uktus and Alapayev districts, thus reinforcing his influence in the area of Beloiarskaia sloboda, which had been founded by his uncle. However, the following year, the chief of the Siberian Oberbergamt, Wilhelm (Vilim) de Gennin, endowed with extraordinary powers, initiated a case against Venedikt on charges of abuse. In particular, Venedikt was accused of extortion, bureaucratic delays (volokita), harbouring of thieves and brigands. Nevertheless, like the representatives of the older Tomilov generation, Venedikt succeeded in escaping punishment. The intention of the Tobol'sk Aulic Court (nadvornyi sud) to protect its jurisdiction from de Gennin's trespass certainly played a significant role ${ }^{179}$ but Venedikt probably made every possible effort to obtain the judges' leniency.

\section{Entrepreneurial activity}

63 Anna Joukovskaia has recently demonstrated that in Sevsk, the entrepreneurial activity of clerks could be very impessive and its income could be superior to both their remuneration and receipts from bribes. ${ }^{180}$ Although the Tomilovs officially occupied a 
higher level than clerks in the social hierarchy, they had much in common. Both prikazchiki and local clerks had relatively low status in comparison with Moscow ranks but enjoyed significant power over the people under their governance and could use it for taking presents and bribes. Consequently, it seems necessary to consult the sources on their entrepreneurial activity.

Different examples of the Tomilovs' economic activity have been cited throughout the paper: lease of homesteads, shops and barns at Irbit fair, distilling alcohol, planting crops. They also possessed a labour force: the house serfs. These activities (in addition to real estate rentals in Irbitskaia sloboda) were typical for many other deti boiarskie. Moreover, it is natural to suggest that with large stocks of grain and cattle at their disposal, the Tomilovs engaged in trade, and so did other deti boiarskie. Yet, no direct documentary evidence has been revealed so far which would permit us to estimate the importance of this source of income. No records on the Tomilovs have been found either in the custom books of the North river route for $1675-1680^{181}$ or in the Verkhotur'e custom book for 1682-1683. ${ }^{182}$ The Verkhotur'e custom book for 1673-1674 does report sales for the Tomilovs, but their volume is not high: Ivan sold two kad' (four chetvert') of rye and a pig carcass, estimated at 60 kopecks, while Fëdor sold eight kad' (16 chetvert'). ${ }^{183}$ Records on other deti boiarskie in the Verkhotur'e custom books are also rare. The only surviving book of deeds (kniga zapisi krepostei) for Tobol'sk for the period under review (1702) testifies that on September 12, 1702, Venedikt Fëdorovich Tomilov hired two uninitiated deti boiarskie and three Cossack's sons (kazach'i deti) for 10 roubles on his doshchanik (wooden flat boat) bound for Tiumen'. ${ }^{184}$ Earlier (on December 30, 1701, and January 15, 1702 , respectively), Venedikt assigned a promissory note for 2.60 roubles in the name of Tobol'sk musketeer Mikula Pavlov Zhuravlëv against a debt of the same value to Timofei Korobov, a man (chelovek) of Governor M.Ia. Cherkasskii, and borrowed 20 roubles from a foreigner (inozemets), Khristofor Levenfeit. These records permit us to affirm that Venedikt Tomilov undertook some entrepreneurial activity; however, we can only guess the nature of this activity. On December 15, 1702, the same Khristofor Levenfeit conceded a serf to Ivan Pankrat'evich Tomilov against a debt of 10 roubles. ${ }^{185}$ The book of deeds shows that, like Ivan Tomilov, most other deti boiarskie occasionally lent or borrowed no more than 10 roubles.

There are also some records about the economic activities of Vasilii Tomilov, the son of above-mentioned Kirilo, Fëdor Tomilov's nephew. He can be identified with Vasilii Tomilov, the officer in charge of bridge maintenance (mostovoi prikazchik) of Uktus district who (together with clerk Alexei Gobov) bought for 72 roubles the monopoly right to the production and sale of vodka (vinnyi otkup), and the right to collect several other duties in Beloiarskaia (1721) and Novopyshminskaia (1722) slobody. ${ }^{186}$ The coincidence in name, surname, age (33), and residence in Beloiarskaia sloboda permits such identification.

There is no doubt that, similarly to other deti boiarskie, the Tomilovs had other sources of income apart from their service and bribes. The existence of such sources of income did not encumber their service. On the contrary, it contributed to its success. However, available data on the Tomilovs' entrepreneurial activity does not seem significant enough to revise the priority of their service as a source of income and identity, as in the case of the clerks of Sevsk. 


\section{Conclusion}

67 At this stage of the research, due to the absence of sufficiently detailed data on the activity of Fëdor and Ivan Tomilov's descendants in subsequent periods, we must stop and draw a preliminary conclusion. What do the biographies of our two "heroes" and their children provide for a better understanding of the development of Western Siberia?

First, it turns out that the career path of the Tomilov brothers and their children has certain logic. From their youth they "specialised" in running settlements; moreover, having "settled" in a particular settlement, they were appointed there as prikazchiki more often than in other places. In Verkhotur'e, prikazchik activity was typical for other deti boiarskie, but they did not, for the most part, get appointments as often as the Tomilovs. In Tobol'sk, where the number of deti boiarskie and administrative functions were higher, such a specialisation in prikazchiki could not fail to represent a more specific phenomenon. Indeed, the careers of two other well-known Tobol'sk residents, Semën Remezov and Fëdor Kachanov, followed a different path. ${ }^{187}$ Thus, we can put forward a hypothesis (which, of course, requires further verification) that within the chin of deti boiarskie, groups with different unofficial service "profiles" and, consequently, with different lifestyles, existed.

69 Secondly, the paper reveals examples demonstrating both the diversity of connections among people of unequal social statuses and the importance of the borders between chiny. One such example is the conflict between the Tomilov brothers and prikazchik of Aramashevskaia sloboda Mikhail Meshcheriakov in 1674. Its analysis reveals, on the one hand, the Tomilovs' close kinship and active daily interactions with the persons from lower status groups involved in the conflict, and, on the other hand, the importance of the boundaries defined by belonging to different levels of the social hierarchy. Intergroup connections were also revealed by the conflict between the Tomilovs and Governor Ivan Tsykler, where priests Ivan Euplov and Parfenii Udimtsov played an active role in avoiding seizure of the Tomilovs' property; “musketeer's son" Fëdor Zav'ialov also took a certain part in the process. These kinds of social networks, as we can see, could prove very efficient, yet historians rarely have a chance to reveal them. ${ }^{188}$

70 The Tomilovs' interactions with public institutions were marked by ambivalence. Throughout their lives, they successfully used these institutions in pursuit of their personal goals or neutralized them apparently through different informal connections and by means of bribery. Indeed, not a single investigation on abuse on the part of the Tomilovs resulted in their punishment. Despite their weak motivation in terms of public interest, their petitions for promotion were granted. Their relative Kirilo Stepanov managed to live his whole life as an uninitiated syn boiarskii, while he obviously had no rights to this status. Neither he nor his son Vasilii were affected by a single conscription (rekrutskii nabor), while certain deti boiarskie could not escape it. ${ }^{189}$

71 At the same time, the Tomilovs (as well as other deti boiarskie) could hardly ignore the emergence of new types of service (dragoon regiment of Tobol'sk, mining and metallurgical administration, special court authorities) as well as attempts to modify the old ones (decrees on the standardization of prikazchik renumeration, on the prohibition of bribes, institution of the post of burmistr, etc.). ${ }^{190}$ They could expect traditional models of participation in the administration to remain inherently unchanged despite all the novelties of Peter's époque, or, alternatively, they could try to master new, more 
"regular" types of service. The second option implied an additional burden (constant military danger in case of service in a dragoon regiment, ${ }^{191}$ a necessity to acquire special knowledge for service in the mining and metallurgical industry, or hard routine and damage to "honour" in the case of service in chancelleries), while the first option required increased competitiveness in the fight for appointments, with the threat of becoming a recruit or of marginalization in case of loss of one's position. Fëdor Tomilov and his children considered themselves able to take the risks involved in the first option in the period under review they seemed to cope with them. Ivan Tomilov chose the second option for his children, even though in a relatively mild variation (they could mostly maintain their former lifestyle). It is reasonable to believe that until some point the border dividing Ivan's descendants, officers (and potentially gentry men), and Fëdor's descendants, simple deti boiarskie, was phantom. Consequently, the adequacy of the official grid of social notions set by the legislation (gentry, ranks, soldier service, kazachestvo, tax per head) is questionable. However, its importance should not be underestimated. Despite the Tomilovs' remarkable ingenuity, the potential to soften implementation of certain norms was limited.

Thus, the census book of Kamyshevkaia sloboda (1748) reports Ivan Fëdorov syn Tomilov, 72 years old, with his son Savva (45 years old) and grandchildren as peasants. ${ }^{192}$ Their ages suggest they are the son and grandson of Fëdor Pankrat'evich Tomilov, who have lost their privileged status. Around the same time, a promemoria of the Siberia governorate office (Sibirskaia gubernskaia kantseliariia) to General Kinderman's camp office on measures for the grain supply of frontier dragoon units records second-mayor Iakov Tomilov, who was sent to seal and inventorize grain in distilleries of Tobol'sk. ${ }^{193} \mathrm{He}$ is very likely to be the son of Vasilii Ivanovich Tomilov. At least his age (he was 13 years old in 1720) makes him suitable for the role. The fortunes of Ivan and Fëdor Tomilov's descendants require special research, but the data cited in the paper suggest that in the long term, the social position achieved through the modified "rules of the game" proved more reliable.

\section{NOTES}

2. Michael Confino, "The soslovie (estate) paradigm: Reflections on some open questions," Cahiers du Monde russe, 49, 4 (2008): 693.

3. Elise Kimerling Wirtschafter, "Social Categories in Russian Imperial History," Cahiers du Monde russe, 50, 1 (2009): 231-250; David L. Ransel, “Implicit Questions in Michael Confino's Essay: Corporate State and Vertical Relationships," Cahiers du Monde russe, 51, 2 (2010): 195-210; Aleksander B. Kamenskii, "Do We Know The Composition of the $18^{\text {th }}$ century Russian Society?" Cahiers du Monde russe, 55, 1 (2014): 135-148.

4. Wirtschafter, "Social Categories in Russian Imperial History," 241.

5. Cf. Anna Joukovskaia's objections to the pertinence of the chin pod'iachie as a "useful approximation" of historical reality in the context of Sevsk: Anna Joukovskaia, "Unsalaried and Unfed: Town Clerks' Means of Survival in Southwest Russia under Peter I," Kritika: Explorations in Russian and Eurasian History, 14, 4 (Fall. 2013): 737. 
6. On the necessity of analyzing large social groups, see: Nikolai E. Koposov, "O nevozmozhnosti mikroistorii [On the impossibility of microhistory]," in Iurii L. Bessmertnyi, Mikhail A. Boitsov, eds., Kazus: Individual'noe i unikal'noe v istorii [Casus: The individual and unique in history], 3 (2000), 36-41.

7. Cf. Iurii Bessmertnyi's argumentation: Iurii L. Bessmertnyi, "Mnogolikaia istoriia (problema interpretatsii micro- i makropodkhodov [Multifaceted history (The problem of integration of micro- and macro- approaches)]," Kazus (2000), 52-61.

8. See for example: Anatolii T. Shashkov, "Voevodskoe upravlevnie na Urale v XVII veke (Verkhoturskii rozysk o sluzhilykh liudiakh 1678-1679 gg. i sud'ba Iu.B. Lepikhina [Military governorship in the Ural region in the seventeenth century (An investigation into servitors in Verkhotur'e district, 1678-1679, and the life of Iu.B. Lepikhin)] in Anatolii T. Shashkov, Izbrannye trudy [Selected works] (Ekaterinburg, 2013), 536-537.

9. Nikolai I. Nikitin, Sluzhilye liudi Zapadnoi Sibiri XVII veka [Servitors in Western Siberia in the seventeenth century] (M.: Nauka, 1988), 75; Shashkov, "Voevodskoe upravlevnie na Urale v XVII veke," 536-537; Iurii V. Konovalov, "Dinastii verkhoturskikh pushkarei [The lineages of Verkhotur'e cannoneers] in Pervye Pokhodiashinskie chteniia. Regional'naia kraevedcheskaia nauchno-prakticheskaia konferentsiia. 3-4 iiulia 2003, Verkhotur'e [First readings in honor of Maksim Pokhodiashin. A regional local history conference. Verkhotur'e, July 3-4, 2003] (Ekaterinburg, 2005), 64-72, on-line: http://www.okorneva.ru/publikatsii--konovalova-yuriyavitalevicha/dinastii-verhoturskih-pushkarey/ (accessed Sept. 3, 2016); *TGIAMZ (Tobol'skii gosudarsvennyi istoriko-arkhitekturnyi muzei-zapovednik - Tobol'sk State Historical Architecture Museum), KP. 12692, 1. 8v.-9 (from now on, a single asterisk * refers to archive documents that the author studied in the form of copies kindly provided by Iurii Vital 'evich Konovalov, vice president of Ural'skoe Istoriko-Rodoslovnoe Obshchestvo (Ural Historical and Genealogical Society - UIRO).

10. Calculation based on the fact that according to the census book for 1669, Fëdor was 23 years old and Ivan16 years old, RGADA (Rossiiskii gosudarstvennyi arkhiv drevnikh aktov - Russian State Archives of Ancient Acts), f. 1111, Verkhoturskaia prikaznaia izba, op. 3, d. 23, 1. 14 ob.).

11. Aleksandr A. Dmitriev, Permskaia starina, [The antiquities of Perm'] vyp. VII (Perm', 1897), 188; *TGIAMZ, KP. 12692, 1. 8 ob.-9. Analysis of the records shows that the age of married people was not reported. For instance, the age of Fëdor's brother Ivan is reported to be 9, for some reason underestimated by three years (while in 1669, Ivan's age is reported to be 16, and 25 in 1679).

12. **NIA SPbII (Nauchno-istoricheskii arkhiv Sankt-Peteburgskogo Instituta Istorii Rossiiskoi Akademii Nauk - Scientific-Historical Archive of St. Petersburg Institute of History of the Russian Academy of Sciences). f. 28, Verkhoturskaia votvodskaia izba, op. 1, d.1244, 1.9-10. A double asterisk ** refers to the information from the card index file of collection no. 28 , kindly provided to the author by Iurii Vladislavovich Sharipov, full member of UIRO.

13. RGADA, f. 214, Sibirskii prikaz, op. 1, d. 509, 1. 261.

14. ${ }^{* *}$ NIA SPbII, f. 28, op. 1, d. 1375 (March 1668), d. 1465 (February-April 1669), d. 1737, 1. 3-4. (October 1670).

15. **NIA SPbII, f. 28 , op. 1 , d. 1/18, 1. 38. The card reports 1671 , i.e., the document was dated 7179 without the exact date. Threshing took place in autumn; autumn 7179 was in 1670.

16. **NIA SPbII, f. 28. [cardboard with unformalized files] d. 16/17, 1. 37-38.

17. Iurii V. Konovalov, "Frol Arapov i Chusovaia sloboda [Frol Arapov and Chusovskaia sloboda]," Chetvërtye "Malye Stroganovskie chteniia," 5 December 2007, Pervoural'sk [Fourth informal Stroganov meeting, December 5, 2007, Pervoural'sk], http://www.okorneva.ru/publikatsii-konovalova-yuriya-vitalevicha/frol-arapov-i-chusovskaya-sloboda/ (accessed Sept. 4, 2016).

18. RGADA, f. 1111, op. 2, d. 793, 1. 11.

19. **NIA SPbII, f. 28, [cardboard with unformalized files] d. 19/17, 1. 9-11. 
20. RGADA, f. 1111, op. 2, d. 240, 1.40; **NIA SPbII, f. 28, [cardboard with unformalized files] d. 19/12, 1.3-5. According to the 1680 census, the sloboda counted 23 villages (Dmitriev, Permskaia starina, vyp. VII, 101).

21. Originally this category of Cossacks was supposed to receive only tax-free (belye) plots of arable land without any money or salt. However, afterwards the Gorvenment also had to grant money in order to make service more attractive.

22. RGADA, f. 1111, op. 2, d. 224, 1. 1-2.

23. RGADA, f. 1111, op. 2, d. 224, 1. 3-5.

24. RGADA, f. 1111, op. 1111, op. 2, d. 224. 1. 1ob., 6 ob.

25. The year [7]182 "from the creation of the world" spans the time from September 1, 1673 to August 31, 1674. The petition was composed at the end of October or at the beginning of November 1674 (the year 7183 "from the creation of the world").

26. RGADA, f. 1111, op. 2, d. 224, 1. 6.

27. RGADA, f. 214, op. 1, d. 487, 1. 621.

28. RGADA, f. 214, op. 1, d. 509, 1. 275.

29. Aleksandr A. Preobrazhenskii, Ural i Zapadnaia Sibir' v kontse XVI - nachale XVII veka [The Urals and Western Siberia from the late sixteenth to the early eighteenth centuries] (M.: Nauka, 1972), 359.

30. RGADA, f. 1111, op. 2, d. 224, 1. 7, 9, 16-23.

31. RGADA, f. 1111, op. 2, d. 224, 1. 10.

32. RGADA, f. 1111, op. 1, d. 98, 1.104 (guarantee for a petitioner from the community of Nev 'ianskaia sloboda, 1689) Ibid., f. 214. op. 1, d. 1322, 1. 48 ob. (guarantee for a murderer, 1702), 96 (guarantee for a person accused of posessing false copper money [vyimochnykh mednykh den 'gakh], 1702).

33. RGADA, f. 1111, op. 2, d. 224, 1. 24.

34. RGADA, f. 1111, op. 2, d. 224, 1. 25. Princess Feodora was born on September 4, 1674, and died on November 28, 1677 (V. Durasov, ed., Rodoslovnaia kniga Vserossiiskogo dvorianstva. Chast' 1 [Genealogy book of Russian nobility, Part 1] (SPb., 1906), 39).

35. Iurii V. Konovalov, "Osnovatel' i stroitel' Nev'ianskogo zavoda Mikhail Afanas'evich Bibikov [Mikhail Afanas'evich Bibikov, Founder and Builder of Nev'iansk Ironworks]," Ocherki istorii kul 'tury i byta starogo Nev'ianska: Liudi, pamiatniki, dokumenty (k 300-letiiu goroda) [Essays on the history, culture and life of old Nev'iansk: People, monuments, documents (commemorating the 300th anniversary)] (Ekaterinburg, 2001), 21-28. Online: http://www.okorneva.ru/publikatsii-konovalova-yuriya-vitalevicha/osnovatel-i-stroitel-nevyanskogo-zavoda-mihail-afanasevichbibikov/ (accessed Sept. 4, 2016).

36. Dmitriev, Permskaia starina, vyp. VII, 187.

37. RGADA, f. 214, op. 1, d. 487, 1. 273 ob.-274.

38. Dmitriev. Permskaia starina, vyp. VII,187.

39. RGADA, f. 214. op. 1, d. 509, 1. 259-259 ob.

40. RGADA, f. 1111, op. 2, d. 240, 1. 41-42.

41. RGADA, f. 1111, op. 1, d. 84, chast' 2, 1. 78.

42. RGADA, f. 1111, op. 2, d. 289, 1. 62-65.

43. *GASO (Gosudarstvennyi Arkhiv Sverdlovskoi Oblasti - State Archive of Sverdlovsk Oblast),

f. 24, Ural'skoe gornoe upravlenie, op. 2, d. 1436, 1. 150-151.

44. RGADA, f. 214. op. 1, d. 746. 1. 108ob.-109.

45. RGADA, f. 1111, op. 4, d. 94, 1. 14ob.

46. RGADA, f. 1111, op. 2, d. 356, 1. 48 (F.P. Tomilov's report on sending carts to Chusovskaia sloboda in order to transport churchware).

47. RGADA, f. 1111, op. 2, d. 366, 1. 71-72.

48. RGADA, f. 1111, op. 4, d. 97, 1. 13. 
49. RGADA, f. 1111, op. 4, d. 100, 1. 13.

50. RGADA, f. 1111, op. 2, d. 392, 1. 13.

51. *RGADA, f. 214. op. 1, d. 748, 1. 77.

52. *RGADA. F.214. op. 1, d. 1524, 1.284. on-line: http://census1710.narod.ru/ perepis/214_1_1524.htm (accessed Sept. 4, 2016).

53. *RGADA, f. 214, op. 1, d. 1617, 1. 737.

54. This information was gathered during a large investigation (bol'shoi sysk) into abuse by prikazchiki and apparently based on documents. Otherwise, the level of their detalization is hard to explain. Sloboda priests, cossacks and bobyli mentioned that prikazchiki changed very often, but they did not remember the exact chronology. RGADA, f. 1111, op. 1, d. 68, chast' 3, 1. 23-25.

55. For arguments against the widespread assertion that the fair had already been sanctioned in 1643, see: Evgenii V. Vershinin, "Irbitskaia sloboda V XVII v. [Irbitskaia sloboda in the seventeenth century]," in Irbitskaia iarmarka: Irbitskaia sloboda i Irbitskaia iarmarka v XVII-XVIII vekakh [Irbitskaia fair: Irbitskaia settlement and Irbitskaia fair in the seventeenth and eighteenth centuries] (Ekaterinburg, 2003), 19-20. For the earliest reference to the fair that we know, see: Sankt-Peterburgskii filial Arkhiva RAN - St. Petersburg Branch of the Archive of the Russian Academy of Science, f. 21, Portfeli Millera, op. 4, d. 3, 1. 20 ob.-21 (1685).

56. RGADA, f. 1111, op. 1, d. 68, chast' 3, 1. 26-27.

57. Ibid.

58. Vladimir D. Puzanov, Voennye faktory russkoi kolonizatsii Sibiri (konets XVI - nachalo XVIII vv.) [Military factors of the Russian colonization of Siberia (late sixteenth - early eighteenth centuries)] (SPb.: Aletejia, 2010), 325.

59. Viktor E. Borisov, "Prikazchiki Irbitskoi slobody v XVII veke. Khronologicheskii perechen' [The officials who ruled Irbitskaia sloboda in the seventeenth century. A chronological list]," Ural 'skii rodoved, vyp 10 (Ekaterinburg, 2011), 4-12; RGADA, f. 1111, op. 4, d.94, 1.15 (service entitlement registry book for 1683-1684: "He was not given the second half of the entitlement because he was on duty running Nev'ianskaia sloboda" [A drugoi poloviny okladu evo dat' ne dovelos', potomu chto on byl v Nev'ianskoi slobode na prikaze]).

60. **NIA SPbII, f. 28, op. 1, [cardboard with unformalized files], d. 8/8, 1. 22.

61. Viktor E. Baidin, ed., Uktus, Uktusskii zavod i ego okrestnosti v XVII - XVIII vv. [Uktus, Uktus' ironworks and its surroundings in the seventeenth and eighteenth centuries] (Ekaterinburg, 2011), 15; RGADA, f. 1111, op. 2, d. 128, chast' III, 1. 487 (Ivan Tsykler's 1695 report to the Siberian Chancellery).

62. *RGADA, f. 214, op. 1, d. 1444, 1. 215 (Ivan Polozov's 1695 census book). Now it is the village (selo) of Karamyshevo, not to be confused with Kamyshevskaia sloboda of Verkhotur'e district, founded in 1667 by Semën Budakov (today's city of Kamyshlov).

63. "A na toi zhe ikh otvodnoi zemli i ugod'iakh podle Pyshmu reku vnov' zavel i postroil slobodu verkhoturskoi syn boiarskoi Ivan Tomilov ne biv chelom velikim gosudariam $\mathrm{v}$ Tobolsku po verkhoturskoi pamiati, a ikh de $\mathrm{k}$ dosmotru ne prizyval i lutchimi mestami i ugod'i zavladel i vsiakoe utesnenie toe slobody zhiteli im, slobodchikom s krest'iany, chiniat." (*RGADA, f. 214, op. 1, d. 1444, 1.233).

64. One chetvert' is equivalent to 210 liters or 12,800 cubic inches of dry volume.

65. *RGADA, f. 214, op. 1, d. 884, 1. 11-11ob.

66. RGADA, f. 1111 , op. 2, d. 351, 1.10 (report on sending Vasilii Andreev, a peasant from Aramashevskaia sloboda accused of arson, to Verkhotur'e).

67. RGADA, f. 1111, op. 1, d. 266, chast' 2, 1. 240.

68. “...vo mnogikh tserkovnykh obidakh i v nalogakh i v boiu i v razorenii i v duhovnykh delakh" (RGADA, f. 1111, op. 2, d. 356, 1. 16).

69. Irina L. Man'kova, "Prikhodskoe dukhovenstvo Zapadnoi Sibiri v sisteme tserkovno-gosudarstvennykh otnoshenii XVII v. [The Parish Clergy in Western Siberia and State/ 
Church Relations in the seventeenth century]," Ural'skii istoricheskii vestnik, no 4 (2011): 87; RGADA, f. 1111, op. 2, d. 356. 1. 16-17.

70. RGADA, f. 1111, op. 2, d. 356, 1. 17.

71. RGADA, f. 1111, op. 2, d. 366, 1. 73.

72. RGADA, f. 1111, op. 2, d. 367, 1. 108.

73. Borisov, "Prikazchiki Irbitskoi slobody v XVII veke," 5, 8-11; RGADA, f. 1111, op. 2, d. 833; *NIA SPbII, f. 28, op. 1 [cardboard with unformalized files], d. 61/6, 1. 10.

74. RGADA, f. 1111, op. 4, d. 97, 1. 13 ob.

75. RGADA f. 1111, op. 2, d. 379, 1. 80-99.

76. RGADA, f. 1111, op. 2, d. 389, 1. 152-174 (petitions addressed to I.P. Tomilov)

77. RGADA, f. 1111, op. 1, d. 68, chast' 3, 1.26-27. In the published chronological list (Borisov, "Prikazchiki Irbitskoi slobody v XVII veke," 10. Il'ia Mironovich Budakov is errouneously referred to as prikazchik of the settlement).

78. RGADA, f. 1111, op. 2, d. 392, 1. 5-6. (Ivan Tomilov's petition to appoint a deputy and memo dated April 30, 1694 on Tikhon Golovkov's appointment).

79. RGADA, f. 1111, op. 2, d. 392, 1. 5-6. Are also named with their patronymic ending -o/evich: M.A. Bibikov (Ibid., 1.4); Fëdor Tomilov (1.13); Ivan Albychev (1.20); Ivan Tyrkov (1.23), Ivan Golenishchev (1.26), Fëdor Kamenskii (1.32). Ivan Tomilov is also referred to with his patronymic ending in several Verkhotur'e memos in 1689 (RGADA, f. 1111, op. 2, d. 367, 1.108, 123).

80. Puzanov, Voennye faktory russkoi kolonizatsii Sibiri (konets XVI - nachalo XVIII vv.), 233.

81. Dmitriev, Permskaia starina, vyp. VII, 187-189.

82. *RGADA, f. 214, op. 1, d. 509, 1. 259-261a ob.

83. *RGADA, f. 1111, op. 3, d.23. 1.10ob.-18 ob.; Iurii V. Konovalov, "Verkhoturskie sluzhilye inozemtsy," Ural'skii rodoved, vyp. 8 (Ekaterinburg, 2009), 43.

84. *RGADA, f. 214, op. 1, d. 1026. 1. 3-5 ob.

85. *RGADA, f. 214, op. 1, d. 1152. 1. 266 ob.-270.

86. Dmitriev, Permskaia starina, vyp. VII, 95-98; 100-101.

87. Viktor I. Shunkov, Ocherki po istorii kolonizatsii Sibiri [Essays on the history of the colonisation of Siberia], M. - L. : Izd-vo AN SSSR, 1946), 208.

88. Borisov, "Prikazchiki Irbitskoi slobody v XVII veke," 5, 8-11.

89. RGADA, f. 1111, op. 4, d. 97 (1691-1692), d. 100 (1693-1694), d. 102 (1697-1698), d. 103 (1698-1699).

90. Those who served as prikazchiki in settlements were not remunerated, as attested by the corresponding records in the books.

91. Shunkov, Ocherki po istorii kolonizatsii Sibiri, 208; RGADA, f. 214, op. 3, d. 1359, chast' 2. 1. 220, 223.

92. Preobrazhenskii, Ural i Zapadnaia Sibir', 358-359.

93. Joukovskaia, “Unsalaried and Unfed...," 721-722, 738-739.

94. Shunkov, Ocherki po istorii kolonizatsii Sibiri, 216-217.

95. The draft of the memo order to start the investigation (it does not seem to have taken effect) is dated as early as November 1698 (RGADA, f. 1111, op. 1, d. 68, chast' $3,1.1$ ).

96. RGADA, f. 214, op. 3, d. 1382, 1. 115-116.

97. RGADA, f. 1111, op. 2, d. 68, chast' 3, 1. 31 (Filka Grigor'ev, Ovdokimka Iumin), 1. 34 (Vasko Nifantov), 1. 35 (Panfilko Brynov), 1. 36 (Pronka Balandin), 1. 52 (Spirka Komornikov).

98. RGADA, f. 214, op. 3, d. 1382, 1. 86.

99. RGADA, f. 1111, op. 1, d. 68 , chast' 3. 1. 35.

100. However, they had been appointed as prikazchiki more often: each of them ran the settlement for about three years in total, while Ivan Tomilov - only around two years. 
101. Judging by the genealogical list made by Iurii V. Konovalov, Kseniia's husband is most likely to be Vasilii (the second) Gerasimov syn Agapitov. He is listed for the last time in the 1680 census (RGADA, f. 214, op. 1, d. 697, 1. 351 ob.-353 ob.), then he and his son Timofei disappear from the archives.

102. RGADA, f. 1111, op. 1, d. 78, chast' $2,1.79 .^{\prime}$

103. RGADA, f. 1111, op. 1, d. 78, chast' 2, 1. 79.

104. RGADA, f. 1111 , op. 1 , d. 78 , chast' $2,1.56-60$.

105. RGADA, f. 1111, op. 1, d. 78, chast' 2, 1. 61-65.

106. RGADA, f. 1111, op. 1, d. 78, chast' 2, 1. 66.

107. RGADA, f. 1111 , op. 1 , d. 312 , chast' $^{\prime} 1,1.2$.

108. RGADA, f. 1111 , op. 1 , d. 312 , chast' $1,1.1$.

109. Isbrandt Ides, Adam Brand, Zapiski o posol'stve v Kitai [Notes on an Embassy to China], (M., 1967), 78-79, 84-85.

110. RGADA, f. 1111 , op. 1 , d. 312 , chast $^{\prime} 1,1.4$.

111. RGADA, f. 1111, op. 1, d. 78, chast' 2, 1. 76.

112. RGADA, f. 1111, op. 1, d. 78, chast' $^{\prime} 2,1.77$.

113. RGADA, f. 1111, op. 1 , d. 78, chast' $2,1.71-73$.

114. RGADA, f. 1111, op. 1, d. 78 , chast' $2,1.68$.

115. One vedro is equivalent to 12.3 litres or 750 cubic inches of liquid volume.

116. RGADA, f. 1111 , op. 1 , d. 312 , chast' $1,1.4$.

117. One osmina is equivalent to 105 litres or 6,400 cubic inches of dry volume.

118. RGADA, f. 1111, op. 1, d. 312, chast' $^{\prime} 1,1.20-23$.

119. Ibid., 1. 24-25.

120. Ibid., 1. 6-7.

121. Ibid., 1. 6-19.

122. Ibid., 1. 27-35.

123. Ibid., 1. 36-39.

124. Borisov, "Prikazchiki Irbitskoi slobody v XVII veke," 10.

125. RGADA, f. 1111, op. 1, d. 312 , chast' $1,1.94$.

126. RGADA, f. 1111, op. 2, d. 389, 1. 110.

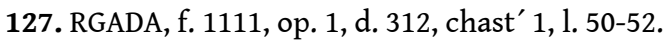

128. "Chiulki viazannye prostye, shuba kitaichataia na belkakh, shapka sobol'ia ponoshena vershek sukonnoi zelenoi etc."

129. "Piat pishchalei starykh," "pansyr staroi na krasnom sukne," "dve sabli prostye chekan da obushek, para pistolei s ol'stry." (RGADA, f. 1111, op. 1, d. 312, chast' 1, 1. 50-52).

130. For data on deti boiarskie's poor supply of weapons in European Russia, see: A.V. Chernov, Vooruzhennye sily Russkogo Gosudarstva v XV - XVII vv. [The Russian State's military forces between the fifteenth and seventeenth centuries] (M.: Voenizdat, 1954), 159-160.

131. RGADA, f. 1111, op. 1, d. 312, chast' $1,1.163$.

132. One pood is equivalent to $16.38 \mathrm{~kg}$ or $36.121 \mathrm{lb}$.

133. RGADA, f. 1111, op. 1 , d. 312 , chast' $1,1.118-119$.

134. RGADA, f. 1111 , op. 1 , d. 312 , chast' $1,1.94$.

135. Akty Istoricheskie, t. V, no $249,458$.

136. RGADA, f. 1111, op. 1, d. 312, chast $^{\prime} 1,1.56-57 ; 123-124$.

137. RGADA, f. 1111 , op. 1 , d. 312 , chast' 1 , 1. 55-56.

138. *TGIAMZ KP. 12700, 1. 13, 14 ob., 28 ob. (their ancestors' common service, 1648); *TGIAMZ, KP. 12692. 1. 5 ob., 8 ob. (neighbourhood, age, 1666)

139. RGADA, f. 1111 , op. 1 , d. 312 , chast' $^{\prime} 1,1.59-60$.

140. RGADA, f. 1111, op. 1, d. 312, chast' $1,1.128-129,131$. 
141. Ibid. 1. 66-70; The time of the Tomilovs' initiation into the deti boiarskie of Tobol'sk can be determined by the fact that in his petition dated July 1 , Ivan Tomilov already mentions it (Akty istoricheskie, t. V, 458). The message is unlikely to have left Tobol'sk earlier than in 1.5-2 months. For delivery time between Tobol'sk and Moscow see: Dmitrii A. Redin, Administrativnye struktury i biurokratiia Urala v epokhu petrovskikh reform (zapadnye uezdy Sibirskoi gubernii v 1711-1727 gg.) [Administrative bodies and bureaucracy in the Urals at the time of Petrine reforms (Western Districts of Siberian Province, 1711-1727)] (Ekaterinburg, 2007), 382-383.

142. One versta- is equivalent to $1.07 \mathrm{~km}$ or 0.66 mile.

143. RGADA, f. 1111, op. 2, d. 128, chast' 3 , 1. 486-487.

144. The gramota containing this information (see footnote below) only mentions 1694-1695. When exactly Ignatii stayed in Irbit has been revealed by archpriest Petr Mangilev (Petr I. Mangilev, "K istorii teksta Zhitiia Simeona Verkhoturskogo [On the textual history of Simeon Verkhoturskii's vita]," Problemy istorii Rossii, vyp. 4 (Ekaterinburg, 2001), 293-301).

145. RGADA, f. 1111, op. 1, d. 312. 1. 62-74; 1. 158-165; Akty istoricheskie, t. V, 459.

146. RGADA, f. 1111, op. 1, d. 312, l. 111.

147. Ibid. 1. 112-139.

148. On the antagonism between ecclesiastic and secular authorities on property issues and questions of the secular courts' jurisdiction over the clergy, see: Nikolai N. Pokrovskii "Sibirskoe delo o desiatil'nikakh [A Siberian Investigation into Tithe Collectors' Activities]," in Nikolai N. Pokrovskii, Rossiiskaia vlast' i obshchestvo XVII - XVIII vv. [Russian authority and society, seventeenth-eighteenth centuries] (Novosibirsk, 2006), 383. The ease with which metropolitan Ignatii excommunicated the tsar's governor while knowing that the property did not belong to him (and while the metropolitan had recently quite successfully cooperated with Ivan Tsykler during the survey about Simeon Verkhoturskii's relics) supports the suggestion that a mental disorder may play a role in the subsequent conflict between Ignatii and patriarch Adrian.

149. RGADA, f. 1111, op. 1, d. 312, 1. 158-165.

150. Akty istoricheskie, t. V, 459-450.

151. RGADA, f. 1111, op. 1, d. 312, 1. 179-187.

152. For an analysis of Tsykler's affair, see: Nina B. Golikova, Politicheskie protsessy pri Petre I: Po materialam Preobrazhenskogo Prikaza [Political processes under Peter I. Based on materials of the Preobrazhenskii office] (M. : Izd-vo Moskovskogo un-ta, 1957), 87-100, 294-296; Paul Bushkovich, Peter the Great, 1671-1725: The Struggle for Power (Cambridge: Cambridge University Press, 2001), 188-197.

153. Mikhail O. Akishin, “Armiia, obshchestvo, kolonizatsiia (Tobol'skii dragunskii polk na Urale v pervoi polovine XVIII v.) [Army, society, colonization (Tobol'sk dragoon regiment in the Urals in the first half of the seventeenth century)] Ural'skii istoricheskii vestnik, no 10, 2011), 276-274; RGADA, f. 214, d. 1310, 1. 408-408 ob., 413; RGADA, f. 214, d. 1310, 1. 408 - 408 ob., 413.

154. A dragoon regiment was formed by the order of December 13, 1698 from belomestnye Cossacks living in southern settlements. (Akishin, “Armiia, obshchestvo, kolonizatsiia," 276-274). 155. Akishin, "Armiia, obshchestvo, kolonizatsiia." On the Siberian dragoon regiment, see also: Andrei V. Dmitriev, Voiska "novogo stroia" v Sibiri vo vtoroi polovine XVII veka [Regiments of a new type in Siberia in the second half of the seventeenth century] (Novosibirsk: SUNTS NGU, 2008), 188-200.

156. *RGADA, f. 214, op. 1, d. 474, 1. 40.

157. *RGADA, f. 214 , op. 1 , d. $474,1.27$ ob.

158. RGADA, f. 214, op. 1, d. 474, 1. 28-29.

159. *RGADA, f. 214 , op. 1 , d. 1376, 1.205. On-line: http://forum.vgd.ru/post/602/35294/ p1130893.htm (accessed Sept. 4, 2016). 
160. *Based on the records in 1680 - 11 years old (*RGADA, f. 214, op. 1, d. 697. 1. 13-13ob., 468ob.), and in 1710 - 43 years old (*RGADA. F.214, op.1, d.1524, 1. 284ob. On-line: http:// census1710.narod.ru/perepis/214_1_1524.htm (accessed Sept. 4, 2016)

161. *RGADA, f. 214, op. 1, d. , 1. 15, 19.

162. *RGADA, f. 214 , op. 1 , d. $1434,1.17,18$ ob.

163. *RGADA, f. 214, op. 1, d. 1434, 1. 181 ob.

164. *RGADA, f. 214, op. 1, d. 1434, 1. 14, 24 ob.

165. *RGADA, f. 214, op. 1, d. 1434. 1. 27, 28. However, there are no reasons to deny the possibility that Fëdor Pankrat'evich Tomilov could continue running the sloboda despite his official retirement.

166. *RGADA, f. 214, op. 1, d. 1473.1.19.

167. Pamiatniki sibirskoi istorii XVIII veka [Memorials of Siberian history of the eighteenth century], Vol. 1. (SPb., 1882), 330-331.

168. *RGADA, f. 214 , op. 1, d. 1473, 1. 28 ob.; *RGADA. f. 214 , op. 1, d. 1499, 1. 425ob., 427 (governor's annual report on the fort and personnel of Shadrinskaia sloboda for 1708).

169. Pamiatniki Sibirskoi Istorii XVIII veka, kn. 1, 344, 393.

170. Ibid., 394-395.

171. RGADA, f. 214, op. 1, d. 1525, 1. 1-1 ob.

172. RGADA, f. 214, op. 1, d. 1525, 1. 304 ob.-305 (Ivan Tomilov), 307 ob.-308 (Vasilii Tomilov)

173. RGADA, f. 214 , op. 1 , d. $1524,1.284$ ob.

174. Ibid.

175. Ibid. 1. 200.

176. Redin, Administrativnye struktury i biurokratiia Urala, 207.

177. In the 1710 census, Ivan Ivanovich Tomilov is reported as being 16 years old (see above), i.e, by 1720 he should be 26 years old. However, this three-year difference does not give grounds to doubt this is the same man.

178. RGADA, f. 214, op. 1, d. 1617, 1. 1234.

179. Mikhail O.Akishin, Rossiiskii absoliutizm i upravlenie Sibir'iu XVIII veka [Russian absolutism and the governance of Siberia in the eighteenth century] (M.: Novosibirsk: Arkheograficheskii tsentr, 2003), 66; Redin, Administrativnye struktury i biurokratiia Urala, 271; Elena V. Borodina, Sudebnaia reforma Petra I na Urale i v Zapadnoi Sibiri [Peter I's judicial reform in the Urals and Western Siberia] (Ekaterinburg: BKI, 2012), 86-87; 100-102; 166-169.

180. Joukovskaia, "Unsalaried and Unfed...," 731-736.

181. Aleksandr I. Iakovlev, ed., Tamozhennye knigi Moskovskogo gosudarstva XVII veka [Custom books of the seventeenth century Moscow State], t. 3 (M. 1951), 629-873.

182. RGADA, f. 214, op. 1, d. 774.

183. Dmitrii Ia. Rezun, ed., Tamozhennye knigi Sibirskikh gorodov XVII veka [Customs books of Siberian towns in the seventeenth century], t. 3: (Novosibirsk: RIPEL plius, 2000), 72, 80.

184. *RGADA, f. 214, op. 1, d. 474, 1. 1200 ob.

185. *RGADA, f. 214, op. 1, d. 474, 1. 1074 ob., 1079.

186. Mikhail A. Kiselev,"Dom, kotoryi postroil Gobov: $\mathrm{K}$ istorii povsednevnosti zhitelei gornozavodskogo Urala 1720-kh gg. [The house that Gobov built: On the history of the daily lives of Ural dwellers in the 1720s]," Desiatye tatishchevskie chteniia. Vserossiiskaia nauchno-prakticheskaia konferentsiia (Ekaterinburg, 21-22 noiabria 2013 ): Materialy [Tenth Meeting in Honor of Vasilii Tatishchev. All-Russian conference (Ekaterinburg, November 21-22, 2013)] (Ekaterinburg, 2013), 89.

187. Leonid A. Goldenberg, Semen Ul'ianovich Remezov: Sibirskii kartograf i geograf [Semen Ul 'ianovich Remezov: A Siberian cartographer and geographer] (M., 1965); Anatolii T. Shashkov, "Delo monakha Feodosiia (materialy k biografii sibirskogo administratora kontsa XVII - nachala XVIII veka F.R. Kachanova) [The case of monk Feodosii (Materials for a biography of 
F.R. Kachanov, Siberian administrator, late seventeenth-early eighteenth centuries)]," Shashkov, Izbrannye trudy, 497-511.

188. Historians paid attention to numerous relatives, including in-laws, of the first Demidovs (Igor' N. Iurkin, Demidovy: Stoletie pobed [The Demidovs: A century of victories] (M., 2013), 40-46; Sergei V. Trofimov, "Novye dannye o proiskhozhdenii i rodstvennom okruzhenii pervykh Demidovykh (materialy dlia rodosloviia) [New data on the background and relatives of the first Demidovs (Genealogical materials)]," Materialy Pervoi Ural'skoi rodovedcheskoi nauchno-prakticheskoi konferentsii. 15-16 noiabria 2001 [Materials of the first genealogical conference. November 15-16, 2001] (Ekaterinburg, 2003), 133-139). However, it is significant that even in this case Demidovs' contacts (evidently dense) with Tula relatives are only revealed in a limited number of situations, mostly in regard to "employment" of Tula relatives by the fabricants.

189. Mikhail O. Akishin, Politseiskoe gosudarstvo i sibirskoe obshchestvo: Ėpokha Petra Velikogo [The Police State and Siberian society: The age of Peter the Great] (Novosibirsk : Izd. Tsentr. "Avtor," 1996), 58; Konovalov, Verkhoturskie sluzhilye inozemtsy, 47-48.

190. Redin, Administrativnye struktury i biurokratiia Urala, 559-561; Akishin, Rossiiskii absoliutizm i upravlenie Sibir'iu, 43, 51-52.

191. "Ordinary" prikazchiki from deti boiarskie also exercised the functions of military chiefs of their settlements and could participate in fights with nomads; however, this mostly implied defence of the forts rather than participation in battles. Moreover, not all the settlements suffered from attacks as often as those where the dragoons were quartered.

192. *RGADA, f. 350, op. 2, d. 899, 1. 376 ob.

193. Ảduard D. Cherniak, ed., Prostranstvo Severnogo Kazakhstana i Sibiri v istoriicheskoi retrospektive XVIII v. (po dokumental'nym publikatsiiam N. Potanina) [The territory of Northern Kazakhstan and Siberia: A historical retrospective, eighteenth century (Based on N. Potanin's Documentary Publications)] (Tomsk: Tomskii universitet, 2013), 44.

\section{ABSTRACTS}

The article reconstructs the lives of Siberian deti boiarskie Ivan and Fëdor Tomilov and their immediate descendants within the framework of the current historiographical debate on the descriptive principles of Russian society in the early modern era. From the mid seventeenth century to the early 1720s, the Tomilov brothers specialized in running peasant settlements (slobody). They very often got appointed in settlements where they had vested economic interests. Their careers are characteristic of only part of Siberian deti boiarskie: this points to the existence of variations in the types of service and in lifestyles within this social category. It comes out from the various descriptions of conflicts recorded in the Verkhotur'e governor's office and Siberian Chancellery archives that the Tomilovs enjoyed support from members of various social groups who, for some of them, were relatives. At the same time, opponents from lower rungs (belomestnye cossacks, peasants) did not forget their lower social status. The Tomilovs, thanks to their connections with members of other social groups, successfully adapted to the state's social legislation, which sometimes proved disadvantageous. However, after Peter's reforms, Ivan's descendants, who served in the newly formed Tobol'sk Dragoon Regiment, had less difficulty keeping their privileged status than Fëdor's, who held on to their traditional way of life as deti boiarskie running settlements. Thus, biographical and microhistorical approaches 
permit both to problematize and corroborate the "grand narratives" of social history based on traditional terminology and focusing on state policy.

L'article reconstruit les biographies des frères Fedor et Ivan Tomilov, cadets de province (deti bojarskie) sibériens, et de leurs descendants immédiats, dans le contexte de la discussion historiographique actuelle sur les principes de description de la société russe de l'époque moderne. Sur la période étudiée (milieu du XVII ${ }^{\mathrm{e}}$ - années $20 \mathrm{du} \mathrm{XVIII}^{\mathrm{e}}$ siècle), les deux frères spécialisés dans la gestion de faubourgs paysans (slobody) surent se créer une sorte de sphère d'influence : d'ailleurs, le plus souvent, ils étaient nommés là où se trouvaient leurs propres intérêts économiques. Cependant, ce type de carrière ne concernait qu'une partie des cadets de province sibériens, ce qui amène à s'interroger sur les autres modes de vie et de service au sein de cette catégorie statutaire. Les situations de conflits que l'auteur saisit à travers la documentation du secrétariat de Sibérie et des bureaux de gouverneur de Verhotur'e montrent que les Tomilov jouissaient du soutien de représentants de groupes sociaux très variés, et ceux de leurs adversaires locaux qui appartenaient à des groupes de statut inférieur (cosaques, paysans) tenaient visiblement compte de leur position subalterne dans la hiérarchie officielle. Grâce à leur réseau local, les deux frères surent s'adapter aux conditions changeantes, parfois défavorables, de la politique sociale du gouvernement central. Quant à la réussite de leurs descendants, elle fut inégale. Les fils d'Ivan, qui choisirent le service militaire dans un régiment de Tobol'sk, réussirent bien mieux à s'adapter aux réformes du règne de Pierre le Grand et à conserver un statut social privilégié que les fils de Fedor, qui cherchaient à conserver le mode de vie traditionnel de cadets de province gérants de faubourgs. Les approches biographiques et micro-historiques permettent ici de problématiser et de confirmer les " grands narratifs » de l'histoire sociale fondés sur la terminologie traditionnelle et centrés sur la politique de l'État.

\section{AUTHOR}

\section{VIKTOR E. BORISOV}

National Research University - Higher School of Economics, vborisov@hse.ru 